\title{
Involvement of Cannabinoid Receptors in the Regulation of Neurotransmitter Release in the Rodent Striatum: A Combined Immunochemical and Pharmacological Analysis
}

\author{
Attila Köfalvi, ${ }^{1,2}$ Ricardo J. Rodrigues, ${ }^{2}$ Catherine Ledent, ${ }^{3}$ Ken Mackie, ${ }^{4}$ E. Sylvester Vizi, ${ }^{1}$ Rodrigo A. Cunha, ${ }^{2}$ and \\ Beáta Sperlágh ${ }^{1}$ \\ ${ }^{1}$ Laboratory of Molecular Pharmacology, Institute of Experimental Medicine, Hungarian Academy of Sciences, Budapest H-1450, Hungary, ${ }^{2}$ Center for \\ Neuroscience of Coimbra, Institute of Biochemistry, Faculty of Medicine, University of Coimbra, 3004-504 Coimbra, Portugal, ${ }^{3}$ Institut de Recherche \\ Interdisciplinaire en Biologie Humaine et Moléculaire, Université Libre de Bruxelles, Brussels B-1070, Belgium, and ${ }^{4}$ Department of Anesthesiology and \\ Department of Physiology and Biophysics, University of Washington, Seattle, Washington 98195
}

\begin{abstract}
Despite the profound effect of cannabinoids on motor function, and their therapeutic potential in Parkinson's and Huntington's diseases, the cellular and subcellular distributions of striatal $\mathrm{CB}_{1}$ receptors are not well defined. Here, we show that $\mathrm{CB}_{1}$ receptors are primarily located on GABAergic (vesicular GABA transporter-positive) and glutamatergic [vesicular glutamate transporter-1 (VGLUT-1)- and VGLUT-2-positive] striatal nerve terminals and are present in the presynaptic active zone, in the postsynaptic density, as well as in the extrasynaptic membrane. Both the nonselective agonist WIN55212-2 [(R)-(+)-[2,3-dihydro-5-methyl-3[(4-morpholinyl)methyl] pyrrolo[1,2,3-de]-1,4-benzoxazinyl]-(1-naphthalenyl)methanone mesylate salt] $\left(\mathrm{EC}_{50}, 32 \mathrm{nM}\right)$ and the $\mathrm{CB}_{1}$-selective agonist ACEA [ $N$-(2chloroethyl)-5Z,8Z,11Z,14Z-eicosatetraenamide] inhibited $\left[{ }^{3} \mathrm{H}\right] \mathrm{GABA}$ release from rat striatal slices. The effect of these agonists was prevented by the $\mathrm{CB}_{1}$-selective antagonists SR141716A [ $N$-(piperidin-1-yl)-5-(4-chlorophenyl)-1-(2,4-dichlorophenyl)-4-methyl-1Hpyrazole-3-carboxamide] $(1 \mu \mathrm{M})$ and AM251 [1-(2,4-dichlorophenyl)-5-(4-iodophenyl)-4-methyl- $N$-1-piperidinyl-1H-pyrazole-3carboxamide trifluoroacetate salt] $(1 \mu \mathrm{M})$, indicating that cannabinoids inhibit the release of GABA via activation of presynaptic $\mathrm{CB}_{1}$ receptors. Cannabinoids modulated glutamate release via both $\mathrm{CB}_{1}$ and non- $\mathrm{CB}_{1}$ mechanisms. Cannabinoid agonists and antagonists inhibited $25 \mathrm{mM} \mathrm{K}^{+}$-evoked [ $\left.{ }^{3} \mathrm{H}\right]$ glutamate release and sodium-dependent $\left[{ }^{3} \mathrm{H}\right]$ glutamate uptake. Partial involvement of $\mathrm{CB}_{1}$ receptors is suggested because low concentrations of SR141716A partly and AM251 fully prevented the effect of WIN55212-2 and CP55940 [5-(1,1dimethylheptyl)-2-[5-hydroxy-2-(3-hydroxypropyl)cyclohexyl]phenol]. However, the effect of $\mathrm{CB}_{1}$ agonists and antagonists persisted in $\mathrm{CB}_{1}$ knock-out mice, indicating the involvement of non- $\mathrm{CB}_{1}, \mathrm{CB}_{1}$-like receptors. In contrast, cannabinoids did not modulate $\left[{ }^{3} \mathrm{H}\right] \mathrm{dopam}-$ ine release or $\left[{ }^{3} \mathrm{H}\right]$ dopamine and $\left[{ }^{3} \mathrm{H}\right] \mathrm{GABA}$ uptake. Our results indicate distinct modulation of striatal GABAergic and glutamatergic transmission by cannabinoids and will facilitate the understanding of the role and importance of the cannabinoid system in normal and pathological motor function.
\end{abstract}

Key words: striatum; cannabinoid; $\mathrm{CB}_{1}$ receptor; knock-out; $\mathrm{GABA}$; glutamate; dopamine; release

\section{Introduction}

The profound motor and behavioral action of cannabinoids are thought to be mainly mediated by $\mathrm{CB}_{1}$ receptors (Howlett et al., 1990; Compton et al., 1996). Indeed, $\mathrm{CB}_{1}$ receptors are present in high density in the basal ganglia (Herkenham et al., 1990, 1991; Mailleux and Vanderhaeghen, 1992). The existence of $\mathrm{CB}_{1}$ receptor mRNA transcripts in the caudate-putamen (Mailleux and

\footnotetext{
Received 0ct. 12, 2004; revised Jan. 25, 2005; accepted Jan. 25, 2005.

This work was supported by grants from the Hungarian Research Foundation (OTKA T037457, TS040736) and Hungarian Ministry of Education (BI0-00142/2001). A.K. was supported by the International Brain Research Organization Research Fellowship. We are grateful to Mária Baranyi, Dr. Ana Rita Costenla, Lilla Papp, and Dr. Nelson Rebola for excellent help.

Correspondence should be addressed to Dr. Beáta Sperlágh, Laboratory of Molecular Pharmacology, Institute of Experimental Medicine, Hungarian Academy of Sciences, P.0. Box 67, Budapest H-1450, Hungary. E-mail: sperlagh@koki.hu.

DOI:10.1523/JNEUROSCI.4232-04.2005

Copyright $\odot 2005$ Society for Neuroscience $\quad$ 0270-6474/05/252874-11\$15.00/0
}

Vanderhaeghen, 1992; Julian et al., 2003) suggests that $\mathrm{CB}_{1}$ receptors are synthesized in striatal GABAergic efferent neurons (for review, see Romero et al., 2002).

The therapeutic role of the endocannabinoid system is now widely recognized (for review, see Di Marzo et al., 2004). Drugs acting at $\mathrm{CB}_{1}$ receptors have therapeutic potential in Huntington's and Parkinson's diseases (for review, see Romero et al., 2002; Brotchie, 2003; Lastres-Becker et al., 2003; van der Stelt and Di Marzo, 2003). Namely, both endocannabinoid levels and $\mathrm{CB}_{1}$ receptor density are selectively altered in the basal ganglia in animal models of Parkinson's and Huntington's diseases (Di Marzo et al., 2000c; Romero et al., 2000; Lastres-Becker et al., 2001a,b; Gubellini et al., 2002; Maccarrone et al., 2003) and in parkinsonian patients (Lastres-Becker et al., 2001a; Hurley et al., 2003). Furthermore, cannabinoids reduce levodopa-induced dyskinesia (Sieradzan et al., 2001; Ferrer et al., 2003). 
The mechanisms of cannabinoid action in the striatum are still unclear. Cannabinoids, applied in vivo, increase striatal dopaminergic transmission (Malone and Taylor, 1999; Melis et al., 2000 ), likely via increasing the neuronal firing in the ventral tegmental area (Robbe et al., 2001) and in the substantia nigra. However, in vitro, they directly did not affect the release of dopamine (Szabo et al., 1999). Cannabinoids depress both GABAergic (Szabo et al., 1998) and glutamatergic [caudate-putamen (Gerdeman and Lovinger, 2001; Huang et al., 2001; Gerdeman et al., 2002; Brown et al., 2003; Ronesi et al., 2004), nucleus accumbens (Robbe et al., 2001, 2002)] synaptic currents through presynaptic $\mathrm{CB}_{1}$ receptor activation. However, we (Köfalvi et al., 2003) and others (Hájos et al., 2001) have recently shown that cannabinoids still decrease glutamate release in the hippocampus in the $\mathrm{CB}_{1}$ $-/-$ mouse. Moreover, the endocannabinoid/endovanilloid agonist anandamide in the $\mathrm{CB}_{1}-/-$ mice and the synthetic cannabinoid/vanilloid agonist arvanil in the wild-type mice depress spontaneous activity and cause catalepsy in a manner independent from $\mathrm{CB}_{1}$ and $\mathrm{TRPV}_{1}$ receptor activation (Di Marzo et al., 2000a,b). Furthermore, both anandamide and the synthetic cannabinoid agonist $(R)-(+)$-[2,3-dihydro-5-methyl(-3 [(4morpholinyl)methyl]pyrrolo[1,2,3-de]-1,4-benzoxazinyl]-(1naphthalenyl)methanone mesylate salt (WIN55212-2) stimulate GTP $\gamma \mathrm{S}$ binding in brain membranes from $\mathrm{CB}_{1}-/-$ mice, although not in the basal ganglia (Di Marzo et al., 2000b; Breivogel et al., 2001; Monory et al., 2002). All of these observations support the notion that there are additional receptors for these ligands (Pertwee, 2004). Therefore, it is important to determine whether $\mathrm{CB}_{1}$ receptors are the only receptors responsible for the presynaptic effect of cannabinoids in the striatum.

Thus, our goals were (1) to analyze the distribution of $\mathrm{CB}_{1}$ receptors to define the colocalization of $\mathrm{CB}_{1}$ immunoreactivity with markers of different types of nerve terminals and (2) to perform a pharmacological analysis of the effect of cannabinoids on the three main striatal neurotransmitters.

\section{Materials and Methods \\ Animals}

All studies were conducted in accordance with the principles and procedures outlined in the National Institutes of Health Guide for the Care and Use of Laboratory Animals and were approved by the local Animal Care Committees of our institutes. $\mathrm{CB}_{1}$ receptor homozygote knock-out mice were generated as described previously (Ledent et al., 1999). The genotype of the mice was tested by the conventional PCR technique on genomic DNA obtained from the tails of experimental animals immediately after the experiments.

\section{Localization of the $C B_{1}$ receptor in rat striatal nerve terminals} Subsynaptic distribution of $C B_{1}$ receptor in the rat striatum. The solubilization of the presynaptic active zone and the extrasynaptic and postsynaptic fractions from rat striatal synaptosomes was performed according to the method described previously (Phillips et al., 2001), with minor modifications. We confirmed previously (Pinheiro et al., 2003) that this subsynaptic fractionation method allows a $>90 \%$ effective separation of markers of the presynaptic active zone (syntaxin and synaptosomeassociated protein of $25 \mathrm{kDa}$ ), postsynaptic density [postsynaptic density-95 (PSD-95) and NMDA receptor subunit 1], and extrasynaptic (synaptophysin) markers and can be used to assess the subsynaptic distribution of metabotropic receptors (Rebola et al., 2003).

Briefly, striata from 12 male Wistar rats were homogenized at $4^{\circ} \mathrm{C}$ with a Teflon-glass homogenizer in $15 \mathrm{ml}$ of isolation solution [0.32 $\mathrm{M}$ sucrose, $0.1 \mathrm{mM} \mathrm{CaCl}_{2}, 1 \mathrm{~mm} \mathrm{MgCl}$, and $0.1 \mathrm{~mm}$ phenylmethylsulfonyl fluoride (PMSF)]. The concentration of sucrose was raised to $1.25 \mathrm{M}$ by the addition of $75 \mathrm{ml}$ of $2 \mathrm{M}$ sucrose and $30 \mathrm{ml}$ of $0.1 \mathrm{mM} \mathrm{CaCl}_{2}$, and the suspension was divided in 10 ultracentrifuge tubes. The homogenate was overlaid with $8 \mathrm{ml}$ of $1.0 \mathrm{M}$ sucrose, $0.1 \mathrm{mM} \mathrm{CaCl}_{2}$, and $5 \mathrm{ml}$ of homogenization solution and centrifuged at $100,000 \times g$ for $3 \mathrm{~h}$ at $4^{\circ} \mathrm{C}$. Synaptosomes were collected at the $1.25 / 1.0 \mathrm{M}$ sucrose interface, diluted $1: 10$ in cold $0.32 \mathrm{M}$ sucrose with $0.1 \mathrm{mM} \mathrm{CaCl}_{2}$, and pelleted $(15,000 \times g$ for $30 \mathrm{~min}$ at $4^{\circ} \mathrm{C}$ ). Pellets were resuspended in $1 \mathrm{ml}$ of $0.32 \mathrm{M}$ sucrose with $0.1 \mathrm{mM} \mathrm{CaCl}_{2}$, and a small sample was taken for gel electrophoresis. The solubilization procedure was also performed as described by Phillips et al. (2001), with minor modifications. Briefly, synaptosomal suspension was diluted 1:10 with cold $0.1 \mathrm{mM} \mathrm{CaCl}_{2}$, and an equal volume of $2 \times$ solubilization buffer (2\% Triton X-100 and $40 \mathrm{~mm}$ Tris, $\mathrm{pH}$ 6.0) was added to the suspension. The membranes were incubated for $30 \mathrm{~min}$ on ice with mild agitation, and the insoluble material (synaptic junctions) was pelleted $\left(40,000 \times g\right.$ for $30 \mathrm{~min}$ at $\left.4^{\circ} \mathrm{C}\right)$. The supernatant (extrasynaptic fraction) was decanted, and the proteins were precipitated with 6 vol of acetone at $20^{\circ} \mathrm{C}$ and recovered by centrifugation $(18,000 \times g$ for 30 $\min$ at $15^{\circ} \mathrm{C}$ ). The synaptic junctions pellet was washed with solubilization buffer, pH 6.0, resuspended in $10 \mathrm{ml}$ of $1 \%$ Triton X-100 and $20 \mathrm{~mm}$ Tris, $\mathrm{pH} 8.0$, incubated for $30 \mathrm{~min}$ on ice with mild agitation, and centrifuged $\left(40,000 \times g\right.$ for $30 \mathrm{~min}$ at $4^{\circ} \mathrm{C}$ ), and the supernatant (presynaptic fraction) was processed as described above. PMSF ( $1 \mathrm{mM}$ ) was added to the suspension in all extraction steps. The pellets from the supernatants and the final insoluble pellet (postsynaptic fraction) were solubilized in $5 \%$ SDS, the protein concentration was determined by the bicinchoninic acid protein assay, and the samples were added to a $1 / 6$ vol of $6 \times$ SDSPAGE sample buffer before freezing at $-20^{\circ} \mathrm{C}$.

Western blot analysis was performed using $30 \mu \mathrm{g}$ of each protein fraction, obtained as described above, which were loaded onto a 7.5\% SDS-PAGE gel and then transferred onto polyvinylidene difluoride membranes. Membranes were blocked for $1 \mathrm{~h}$ at room temperature in $5 \%$ low-fat milk in Tris-buffered saline medium with $0.1 \%$ Tween 20 (Merck-Schuchardt, Munich, Germany). The membranes were probed with a rabbit antibody raised against the last 15 aa of the $\mathrm{C}$-terminal of the rat $\mathrm{CB}_{1}$ receptor $(1: 5000)$ overnight at $4^{\circ} \mathrm{C}$. Detection was performed using the alkaline phosphatase-conjugated secondary antibody of goat anti-rabbit IgG (1:20,000; Amersham Biosciences, Little Chalfont, UK). Immunoblots were visualized using the enhanced chemifluorescence detection reagent (Amersham Biosciences). The specificity of $\mathrm{CB}_{1}$ receptor antibody has been confirmed by the laboratory of origin and by the lack of immunostaining in the $\mathrm{CB}_{1}$ receptor knock-out mice (Katona et al., 2001).

Localization of $C B_{1}$ receptor immunoreactivity in different nerve terminals of the rat and mouse striatum. For immunochemical analysis, synaptosomes from striata of male Wistar rats (6 weeks old) and male CD-1 mice (see above) were obtained through a discontinuous Percoll gradient, following the procedure described by Díaz-Hernandez et al. (2002), with minor modifications. Striata were homogenized in $0.25 \mathrm{M}$ sucrose and $5 \mathrm{~mm} \mathrm{~N}$-[tris[hydroxymethyl]methyl]-2-aminoethanesulfonic acid (TES), pH 7.4. The homogenate was spun for $3 \mathrm{~min}$ at $2000 \times g$ at $4^{\circ} \mathrm{C}$, and the resulting supernatant was spun again at $9500 \times g$ for $13 \mathrm{~min}$. Then the pellets were resuspended in $8 \mathrm{ml}$ of $0.25 \mathrm{M}$ sucrose and $5 \mathrm{~mm}$ TES, pH 7.4. Two milliliters of this synaptosomal suspension were placed onto $3 \mathrm{ml}$ of Percoll discontinuous gradients containing $0.32 \mathrm{M}$ sucrose, 1 mM EDTA, 0.25 mm dithiothreitol, and 3, 10, or 23\% Percoll, pH 7.4. The gradients were centrifuged at $25,000 \times g$ for $11 \mathrm{~min}$ at $4^{\circ} \mathrm{C}$. Synaptosomes were collected between the 10 and $23 \%$ Percoll bands and diluted in $15 \mathrm{ml}$ of HEPES-buffered medium (in mM: $140 \mathrm{NaCl}, 5 \mathrm{KCl}, 5 \mathrm{NaHCO}_{3}, 1.2$ $\mathrm{NaH}_{2} \mathrm{PO}_{4}, 1 \mathrm{MgCl}_{2}, 10$ glucose, and 10 HEPES, pH 7.4).

The striatal synaptosomes were placed onto coverslips previously coated with poly-L-lysine, fixed with $4 \%$ paraformaldehyde for $15 \mathrm{~min}$, and washed twice with PBS (in mM: $140 \mathrm{NaCl}, 3 \mathrm{KCl}, 20 \mathrm{NaH}_{2} \mathrm{PO}_{4}, 15$ $\mathrm{KH}_{2} \mathrm{PO}_{4}, \mathrm{pH}$ 7.4). Permeabilization was performed in PBS containing $0.2 \%$ Triton X-100 for $10 \mathrm{~min}$, and afterward the synaptosomes were incubated in PBS medium containing 3\% bovine serum albumin (BSA) and $5 \%$ normal rat serum for $1 \mathrm{~h}$. The synaptosomes were then washed twice with $\mathrm{PBS}$ and incubated with rabbit anti-CB $\mathrm{CB}_{1}$ receptor and chicken anti-vesicular glutamate transporter (VGLUT)-1 (1:5000; Alpha Diagnostic, San Antonio, TX) and guinea pig anti-VGLUT-2 (1:5000; Chemicon, Temecula, CA), or guinea pig anti-vesicular GABA transporter (VGAT; 1:1000; Calbiochem, Darmstadt, Germany), or mouse antityrosine hydroxylase (Tyr-OH; 1:1000; Chemicon), or mouse anti- 
synaptophysin (1:200; Sigma, St. Louis, MO) antibody for $1 \mathrm{~h}$ at room temperature. The synaptosomes were then washed three times with PBS/ BSA $(3 \%)$ and incubated for $1 \mathrm{~h}$ at room temperature with AlexaFluor488 (green)-labeled goat anti-rabbit IgG antibodies (1:200; Molecular Probes, Leiden, The Netherlands) and goat anti-chicken or goat antiguinea pig or goat anti-mouse antibodies, all labeled with AlexaFluor598 (red; 1:200 for all; Molecular Probes). After washing and mounting on slides with Prolong Antifade (Molecular Probes), the preparations were visualized in an Axiovert 200 (Zeiss, Oberkochen, Germany) inverted microscope equipped with a cooled CCD camera and analyzed with MetaFluor 4.0 software (Universal Imaging Corporation, West Chester, PA).

\section{Release experiments}

Four male Wistar rats (140-160 g; Gedeon Richter, Budapest, Hungary) or five male young adult mice (20-22 g) were decapitated under ether anesthesia, and the brains were quickly put into ice-cold Krebs' solution of the following composition (in mM): $115 \mathrm{NaCl}, 4.7 \mathrm{KCl}, 1.2 \mathrm{KH}_{2} \mathrm{PO}_{4}$, $1.2 \mathrm{MgSO}_{4}, 2.5 \mathrm{CaCl}_{2}, 25 \mathrm{NaHCO}_{3}$, and 10 glucose, oxygenated with $95 \%$ $\mathrm{O}_{2}$ and $5 \% \mathrm{CO}_{2}, \mathrm{pH}$ 7.4. All striata were dissected rapidly and used for slice or synaptosomal experiments. For slice experiments, $400 \mu \mathrm{m}$ slices were cut with a Mcllwain tissue chopper (Bachofer, Reutlingen, Germany) and used for incubation (see below). A synaptosomal fraction of the striatum was prepared with slight modifications of the technique described previously (Cunha and Ribeiro, 2000; Köfalvi et al., 2003). The removed striata were homogenized in ice-cold $0.32 \mathrm{M}$ sucrose solution (containing $1 \mathrm{~mm}$ EDTA, $1 \mathrm{mg} / \mathrm{ml} \mathrm{BSA}$, and 5 mм HEPES, $\mathrm{pH} 7.4$ ) at $4^{\circ} \mathrm{C}$ and centrifuged at $2000 \times g$ for $10 \mathrm{~min}$. The supernatant was centrifuged at $13,000 \times g$ for $12 \mathrm{~min}$. The pellet was resuspended in ice-cold $45 \%$ (v/v) Percoll in Krebs' solution, $\mathrm{pH}$ 7.4, and centrifuged at 13,000 $\times \mathrm{g}$ for 2 min to eliminate free mitochondria and glial debris. The top layer was washed twice at $13,000 \times g$ for $2 \mathrm{~min}$ in oxygenated Krebs' solution at $4^{\circ} \mathrm{C}$.

$\left[{ }^{3} \mathrm{H}\right] \mathrm{GABA}$ and $\left[{ }^{3} \mathrm{H}\right]$ dopamine release experiments from striatal slices. The experiments were performed as described previously (Milusheva et al., 1996; Köfalvi et al., 2000), with slight modifications. Briefly, slices were incubated for $30 \mathrm{~min}$ at $37^{\circ} \mathrm{C}$ in the presence of $5 \mu \mathrm{Ci}$ of $\left[{ }^{3} \mathrm{H}\right] \mathrm{GABA}$ or $\left[{ }^{3} \mathrm{H}\right]$ dopamine $\left(\left[{ }^{3} \mathrm{H}\right] \mathrm{DA}\right)$ in $1 \mathrm{ml}$ of Krebs' solution (Amersham Biosciences). In the case of $\left[{ }^{3} \mathrm{H}\right] \mathrm{GABA}$, the incubation solution contained 1 mм $\beta$-alanine to minimize $\left[{ }^{3} \mathrm{H}\right] \mathrm{GABA}$ uptake into glial cells. After the incubation, four slices were transferred into a polypropylene perfusion chamber and presuperfused (washed) for $1 \mathrm{~h}$. All solutions for $\left[{ }^{3} \mathrm{H}\right] \mathrm{GABA}$ release experiments contained the GABA transaminase (GABA-T)/GAD inhibitor aminooxyacetic acid $(200 \mu \mathrm{M})$, whereas for $\left[{ }^{3} \mathrm{H}\right] \mathrm{DA}$ experiments, all solutions contained ascorbic acid $(0.3 \mathrm{~mm})$ and EDTA (0.03 mm).

After termination of the $1 \mathrm{~h}$ presuperfusion period, 3 min samples were collected for tritium assay (sample collection period). At 6 and 36 min after the start of the sample collection period, the release of $\left[{ }^{3} \mathrm{H}\right]$ transmitters was stimulated twice $\left(\mathrm{EFS}_{1}\right.$ and $\mathrm{EFS}_{2}$ ) with electrical field stimulation (at $40 \mathrm{~V}, 2 \mathrm{~Hz}, 1 \mathrm{~ms}, 360$ bipolar, square-wave pulses; except where noted otherwise), delivered by a Grass S88 Stimulator (Grass Medical Instruments, Quincy, MA) via a pair of platinum ring electrodes. Throughout the experiments, the temperature was maintained at $37^{\circ} \mathrm{C}$. All drugs were introduced $20 \mathrm{~min}$ before the first or the second electrical field stimulation, as indicated later.

$\left[{ }^{3} \mathrm{H}\right]$ Glutamate release experiments from striatal synaptosomes. The experiments were performed with slight modifications of our previous study (Köfalvi et al., 2003). The synaptosomes were diluted to $1.5 \mathrm{ml}$ with Krebs' solution and equilibrated with careful oxygenation $\left(95 \% \mathrm{O}_{2}\right.$ and $5 \% \mathrm{CO}_{2}$ ) at $37^{\circ} \mathrm{C}$ for $5 \mathrm{~min}$, after which $4 \mu \mathrm{Ci}$ of $\left[{ }^{3} \mathrm{H}\right]$ glutamate (Amersham Biosciences) was added to the synaptosomes for $5 \mathrm{~min}$. All solutions contained the GABA-T/GAD inhibitor aminooxyacetic acid (200 $\mu \mathrm{M})$. Ninety-microliter aliquots ( $\sim 610 \mu \mathrm{g}$ of protein) of the preloaded synaptosomes were transferred into $100 \mu \mathrm{l}$ volume superfusion chambers of a 12-channel suprafusion system (Brandel, Gaithersburg, MD), trapped between two layers of Whatman (Maidstone, UK) GF/C filters, and superfused continuously at a rate of $0.5 \mathrm{ml} / \mathrm{min}$ until the end of the experiment. At $12 \mathrm{~min}$ after the start of the $45 \mathrm{~min}$ washout period,
D-aspartate (50 $\mu \mathrm{M}$; Sigma) was administered for 5 min to effectively reduce the $\mathrm{Ca}^{2+}$-independent release of glutamate evoked by high $\mathrm{K}^{+}$ (Terrian et al., 1991; Köfalvi et al., 2003). After termination of the $45 \mathrm{~min}$ washout, 3 min samples were collected for liquid scintillation assay. All experimental periods were performed at $37^{\circ} \mathrm{C}$. At 6 and $36 \mathrm{~min}$ after the start of the sample collection period, the release of $\left[{ }^{3} \mathrm{H}\right]$ glutamate was stimulated twice $\left(\mathrm{S}_{\mathrm{K} 1}\right.$ and $\mathrm{S}_{\mathrm{K} 2}$ ) with $25 \mathrm{~mm} \mathrm{~K}^{+}$(isomolar substitution of $\mathrm{Na}^{+}$by $\mathrm{K}^{+}$in the buffer) for $3 \mathrm{~min}$. The antagonists were given $20 \mathrm{~min}$ before $S_{\mathrm{K} 1}$ (except where noted otherwise), whereas the agonists were given 20 min before $S_{K 2}$, both being present until the end of the experiments.

Validation of transmitter release. The tritium distribution in the effluent, under basal condition and stimulation, was analyzed by HPLC with fluorometric detection as described previously (Nakai et al., 1999). The majority of tritium represented the respective transmitters (GABA, glutamate, and dopamine), according to our previous findings. Tetrodotoxin (TTX) ( $1 \mu \mathrm{M} ; n=4$ in all cases) strongly inhibited the release of $\left[{ }^{3} \mathrm{H}\right] \mathrm{DA}$ (by $76.5 \pm 3.1 \%$; $p<0.001$ vs control) and $\left[{ }^{3} \mathrm{H}\right] \mathrm{GABA}$ (by $77.0 \pm 8.4 \% ; p<0.001$ vs control), indicating that they are released in response to axonal activity. In the case of synaptosomal experiments, when a $\mathrm{Ca}^{2+}$-free buffer supplemented with 1 mm EGTA was superfused after the first stimulation with $\mathrm{K}^{+}$, the subsequent $\mathrm{K}^{+}$-evoked release of $\left[{ }^{3} \mathrm{H}\right]$ glutamate was reduced by $71.3 \pm 6.1 \%(n=4 ; p<0.001$ vs control $)$ in the rat.

Uptake experiments. The uptake of $\left[{ }^{3} \mathrm{H}\right] \mathrm{GABA}$ and $\left[{ }^{3} \mathrm{H}\right] \mathrm{DA}$ into slices and $\left[{ }^{3} \mathrm{H}\right]$ glutamate into synaptosomes was investigated in the absence and presence of cannabinoid ligands. To study the uptake of GABA or $\mathrm{DA}$, the incubation with the isotope was performed as described above, at $37^{\circ} \mathrm{C}$. After a $30 \mathrm{~min}$ incubation, the slices were rinsed three times, weighed, and homogenized, and the tritium content of the homogenates was assayed and expressed in milligrams of tissue weight. For $\left[{ }^{3} \mathrm{H}\right]$ glutamate uptake experiments, after a 5 min equilibration with continuous gassing at $37^{\circ} \mathrm{C}, 50 \mu \mathrm{l}$ aliquots of the preparation was transferred into 450 $\mu l$ of incubation solution containing the drugs or their vehicle (vehicle control). After a $20 \mathrm{~min}$ incubation at $37^{\circ} \mathrm{C}$, the uptake was terminated on ice, and the synaptosomes were washed three times at $15,000 \times g$ for $5 \mathrm{~min}$, diluted and sonicated in $10 \%$ trichloroacetic acid, and assayed for tritium. The uptake of glutamate was strongly dependent on sodium ( $8.0 \pm 0.4 \%$ of control; $n=6 ; p<0.001$ when sodium was replaced by choline chloride) and on temperature ( $12 \pm 2.3 \%$ of control; $n=6 ; p<$ 0.01 at $12^{\circ} \mathrm{C}$ ).

Radioactivity assay and calculations. The radioactivity released from the preparations was measured with a Packard (Canberra, Australia) 1900 Tricarb liquid scintillation spectrometer, equipped with Dynamic Color Corrected DPM Option providing absolute activity (DPM) calculation and correction for different color quenching. The release of the transmitters was calculated as the percentage of the amount of radioactivity in the tissue at the sample collection time [fractional release (FR\%)]. The tissue/synaptosomal tritium uptake was determined as the sum release plus the tissue/synaptosomal content after the experiment. The stimulation-evoked release of the transmitters was calculated by the area-under-the-curve method. All data represent mean \pm SEM of $n \geq 4$ observations. $\mathrm{EC}_{50}$ values were calculated by fitting the data to sigmoidal logistic equations using the Prism 4.00 (Graph Pad, San Diego, CA) program. When the decrease in baseline was calculated, the tritium content of the last sample before the second stimulus was expressed as the percentage of the tritium content of the last sample before the first stimulus. Statistical significance was calculated by Student's $t$ test or ANOVA, followed by Bonferroni's test for selected pairs of columns, as appropriate, and $p<0.05$ was accepted as significant change.

Drugs. TTX, $\mathrm{Na}_{2} \mathrm{CNQX}, \mathrm{AP}-5$, and bicuculline methobromide (all from Sigma) were dissolved in distilled water. WIN55212-2 and $S(-)$-[2,3dihydro-5-methyl-3-[(4-morpholinyl)methyl]pyrrolo[1,2,3-de]-1,4benzoxazinyl]-(1-naphthalenyl)methanone mesylate salt (WIN55212-3) (both from Sigma) were dissolved in $0.1 \mathrm{M} \mathrm{HCl}$. Sulpiride (Sigma), 5-(1,1dimethylheptyl)-2-[5-hydroxy-2-(3-hydroxypropyl)cyclohexyl]-phenol (CP55940),N-(2-chloroethyl)-5Z,8Z,11Z,14Z-eicosatetraenamide(ACEA), $\Delta^{9}$ tetrahydrocannabinol ( $\Delta^{9}$-THC), 1-(2,4-dichlorophenyl)-5-(4-iodophenyl)-4methyl- $N$-1-piperidinyl-1H-pyrazole-3-carboxamide trifluoroacetate salt 
(AM251) (all from Tocris, Bristol, UK), and $N$-(piperidin-1-yl)-5-(4chlorophenyl)-1-(2,4-dichlorophenyl)-4-methyl-1 H-pyrazole-3-carboxamide (SR141716A) (National Institute on Drug Abuse, Bethesda, MD) were dissolved in ethanol. The maximum concentrations of vehicles used had no significant effect on the release of the transmitters.

\section{Results}

Subsynaptic distribution of $\mathrm{CB}_{1}$ receptor in the rat striatum The method of solubilization of subsynaptic fractions allows the antibodies to access the presynaptic active zone and the postsynaptic density, which provided the opportunity to explore the subsynaptic $\mathrm{CB}_{1}$ receptor distribution. This technique appears to be far more sensitive than classical immunogold electron microscopy for determining the localization of synaptic receptors (Phillips et al., 2001; Rebola et al., 2003). Western blot analyses of the subsynaptic fractions showed significant $\mathrm{CB}_{1}$ immunoreactivity in all fractions. The total amount of synaptic $\mathrm{CB}_{1}$ receptors from the initial fraction is denoted as "whole" in Figure 1, representing $100 \%$. After fractionation, we found nearly $23 \%$ of the synaptic $\mathrm{CB}_{1}$ receptors in the presynaptic active zone (Fig. 1, pre) and nearly $30 \%$ of them in the postsynaptic density (Fig. 1, post), where electron microscopy generally cannot localize them, likely because of antibody accessibility problems. The rest of the $\mathrm{CB}_{1}$ receptor immunoreactivity was found in the extrasynaptic fraction of presynaptic and postsynaptic sides (Fig. $1 A, B$, extra).

\section{Localization of $\mathrm{CB}_{1}$ receptor immunoreactivity in different} nerve terminals of the rat striatum

The protocol for separation of nerve terminals is designed to exclude contamination by postsynaptic elements. Nonetheless, we stained the nerve terminals for PSD-95, a postsynaptic marker protein, and observed a very low $(\sim 0.01 \%)$ number of PSD-95positive elements in synaptophysin-costained plates of synaptosomes (data not shown), establishing the specificity of the isolation procedure. Figure 2, $A$ and $B$, illustrates that a high percentage $(60 \%)$ of nerve terminals (identified by synaptophysin) display $\mathrm{CB}_{1}$ receptor immunoreactivity, according to the well known strong $\mathrm{CB}_{1}$ receptor expression in the striatum (Herkenham et al., 1990, 1991; Mailleux and Vanderhaeghen, 1992). Approximately 2000 synaptosomes were counted for each marker [i.e., VGAT (for GABAergic axon terminals; rat), VGLUT-1 and VGLUT-2 (for glutamatergic axon terminals; rat and mouse), and Tyr-OH (for catecholaminergic axon terminals; rat)] and for the $\mathrm{CB}_{1}$ receptor. The strong $\mathrm{CB}_{1}$ receptor density in GABAergic terminals is in agreement with previous morphological data (for review, see van der Stelt and Di Marzo, 2003). With respect to glutamatergic terminals, the presence of $\mathrm{CB}_{1}$ receptors was expected based on electrophysiological observations (Gerdeman and Lovinger, 2001; Huang et al., 2001; Brown et al., 2003; Ronesi et al., 2004). Only a low percentage of $\mathrm{CB}_{1}$ receptor immunoreactivity colocalized with Tyr-OH immunoreactivity, which is a marker for both noradrenergic and dopaminergic terminals.

\section{$\left[{ }^{3} \mathrm{H}\right] \mathrm{GABA}$ release from rat striatal slices}

After the $1 \mathrm{~h}$ washout period, the basal $\left[{ }^{3} \mathrm{H}\right] \mathrm{GABA}$ efflux amounted to $0.192 \pm 0.010 \mathrm{FR} \%(n=10)$, similar to that in the hippocampus (Katona et al., 1999; Köfalvi et al., 2000). The $\left[{ }^{3} \mathrm{H}\right]$ GABA release evoked by the first electrical stimulation (40 $\mathrm{V}, 2 \mathrm{~Hz}, 1 \mathrm{~ms}, 360$ shocks, $\mathrm{EFS}_{1}$ ) was $0.221 \pm 0.041 \mathrm{FR} \%$, whereas the $\mathrm{EFS}_{2} / \mathrm{EFS}_{1}$ value was $0.958 \pm 0.091$ (Fig. $3 A-C$ ). Although the nonselective cannabinoid agonist WIN55212-2 (0.01-1 $\mu \mathrm{M})$ failed to affect the basal (resting) release, it concentration depen-
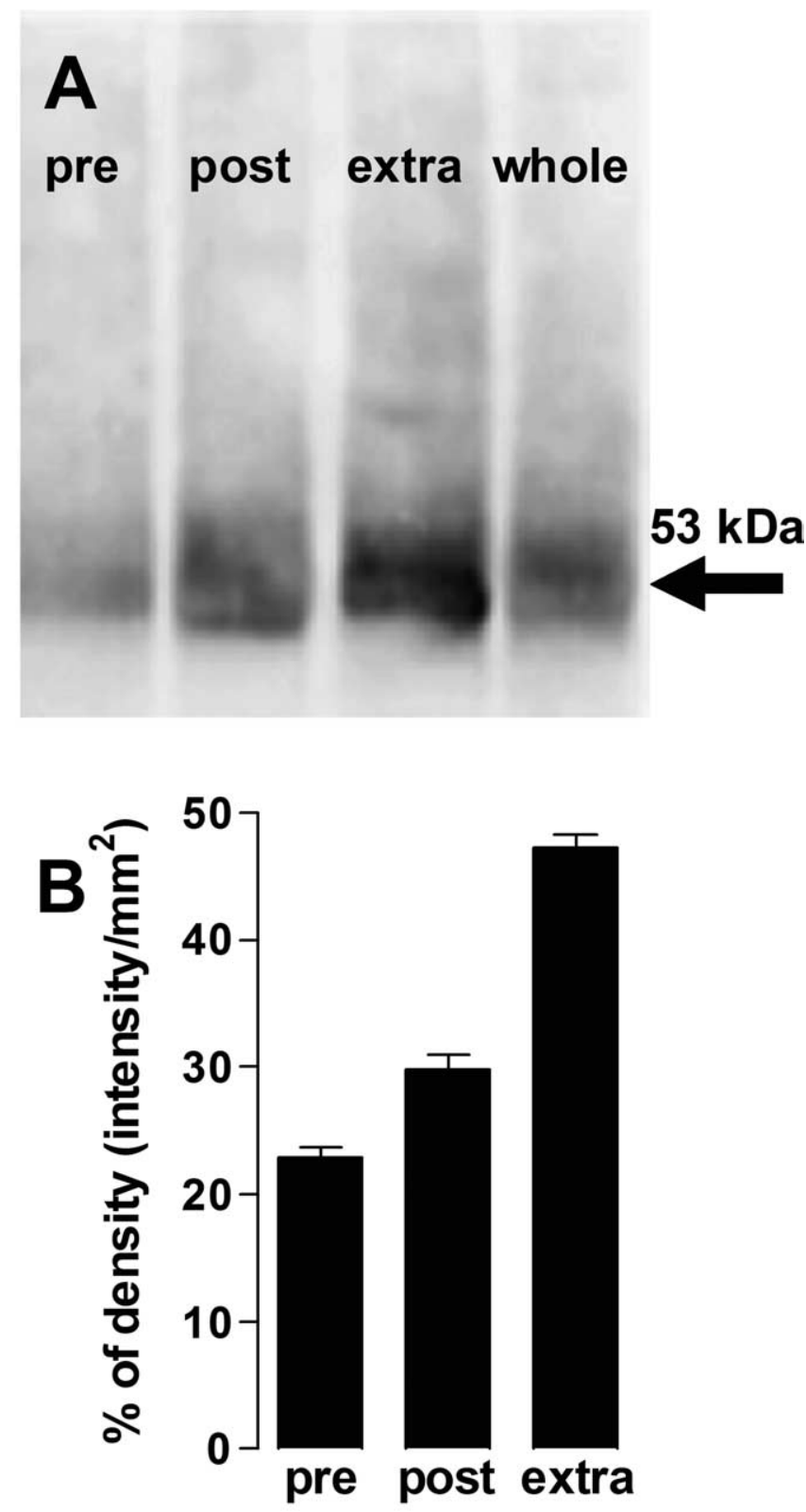

Figure 1. $\quad C_{1}$ receptors are located mainly extrasynaptically but also at the presynaptic active zone and at the postsynaptic density of rat striatal nerve terminals. $\boldsymbol{A}$, Western blot (representative of 4 similar blots from different groups of animals) comparing $C_{1}$ receptor immunoreactivity, corresponding to the $53 \mathrm{kDa}$ band, in a fraction enriched in the presynaptic active zone (pre), in the postsynaptic density (post), in the nerve terminals portion outside the active zone (extra), and in the initial synaptosomal fraction (whole), from which fractionation was performed. These fractions were obtained by $\mathrm{pH}$ fractionation, after solubilization of purified striatal nerve terminals as described in Materials and Methods. Thirty micrograms of protein of each fraction were applied into the SDS-PAGE gel, and a $C_{1}$ antibody was used at a 1:5000 dilution. $\boldsymbol{B}$, Average distribution of $C_{1}$ receptor immunoreactivity in subsynaptic compartments. The $\mathrm{CB}_{1}$ receptor density was higher in the extrasynaptic fraction but was also present, to a lesser extent, in the presynaptic active zone and in the postsynaptic density.

dently and significantly diminished the evoked $\left[{ }^{3} \mathrm{H}\right] \mathrm{GABA}$ release, with an $\mathrm{EC}_{50}$ value of $32 \mathrm{~nm}$ (Fig. $3 A, B$ ). The maximal effect was obtained at $1 \mu \mathrm{M}(42 \%$ inhibition; $n=13 ; p<0.01)$. ACEA, the highly $\mathrm{CB}_{1}$ receptor-selective agonist $(1 \mu \mathrm{M})$, also inhibited the evoked $\left[{ }^{3} \mathrm{H}\right]$ GABA release by $27 \%(n=8 ; p<0.05)($ Fig. $3 B)$. AM251 $(1 \mu \mathrm{M} ; n=6)$ and SR141716A $(1 \mu \mathrm{M} ; n=4)$, the two $\mathrm{CB}_{1}$ receptor-selective antagonists introduced before the first stimu- 

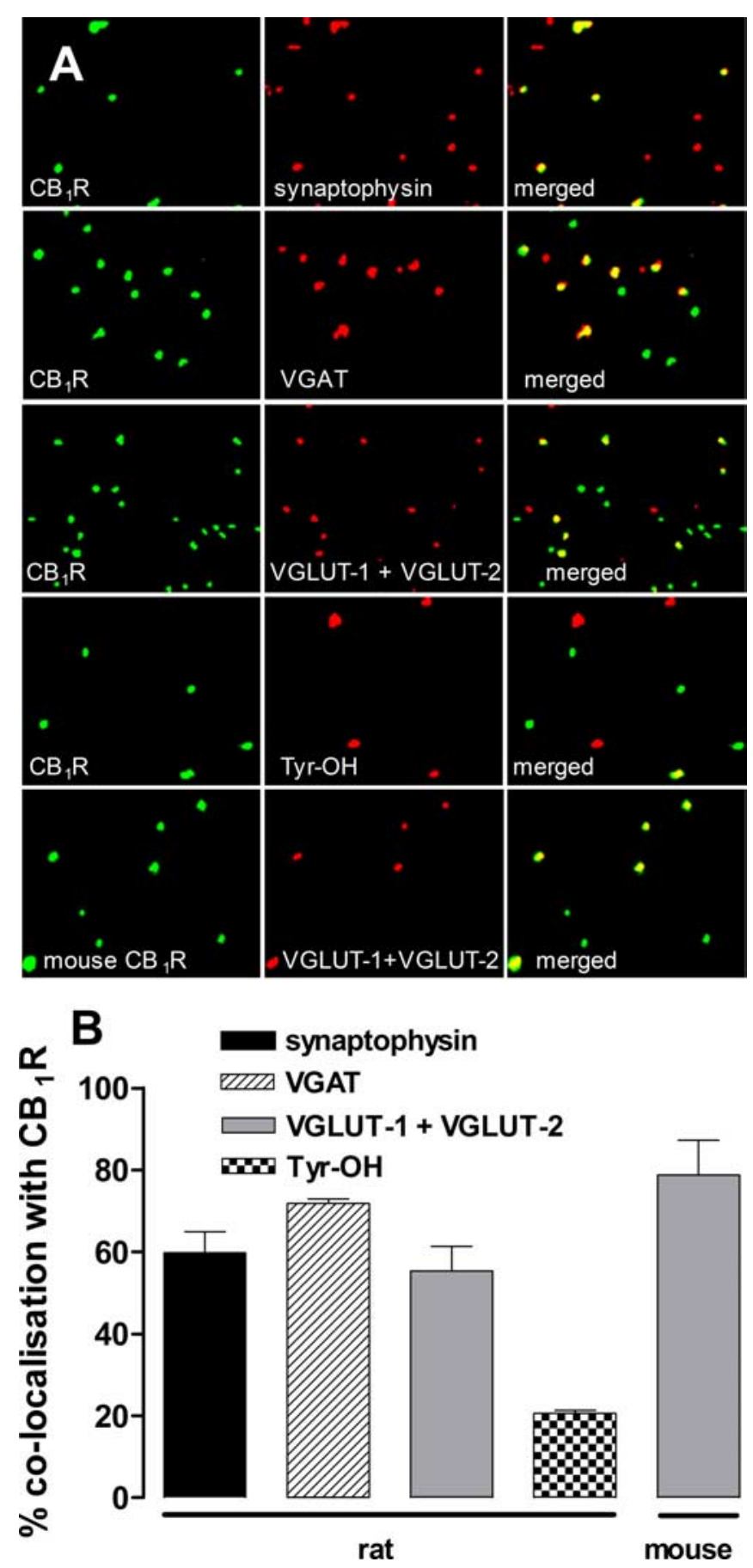

Figure 2. $\quad\left(B_{1}\right.$ receptors are present on GABAergic (from rat) and glutamatergic (from rat and mouse) and, to a lesser extent, on catecholaminergic (from rat) terminals. $A$, Representative double-labeling images of anti- $\mathrm{CB}_{1}$ receptor $\left(\mathrm{CB}_{1} \mathrm{R}\right)$ with anti-synaptophysin (marker of all nerve terminals), anti-VGAT (specific marker of GABAergic nerve terminals), anti-VGLUT-1 and anti-VGLUT-2 (specific markers of glutamatergic nerve terminals), and anti-Tyr-OH (specific marker of catecholaminergic nerve terminals). $B, A$ summary of the extent of $C B_{1}$ receptor colocalization with the specific markers of each type of nerve terminal (mean $\pm \operatorname{SEM}$ of $n=$ 4-6 plates) after counting $\sim 2000$ terminals for each marker.

lation, prevented the inhibition by WIN55212-2 (1 $\mu \mathrm{M})$, whereas they alone had no effect on the release (Fig. $3 C$ ). The ionotropic glutamate receptor antagonists AP-5 $(50 \mu \mathrm{M})$ and CNQX (10 $\mu \mathrm{M})$, all introduced before the first stimulation, did not affect the action of WIN55212-2 $(1 \mu \mathrm{M})$ on the evoked $\left[{ }^{3} \mathrm{H}\right] \mathrm{GABA}$ release $(n=8 ; p<0.05)$ (Fig. 3C).
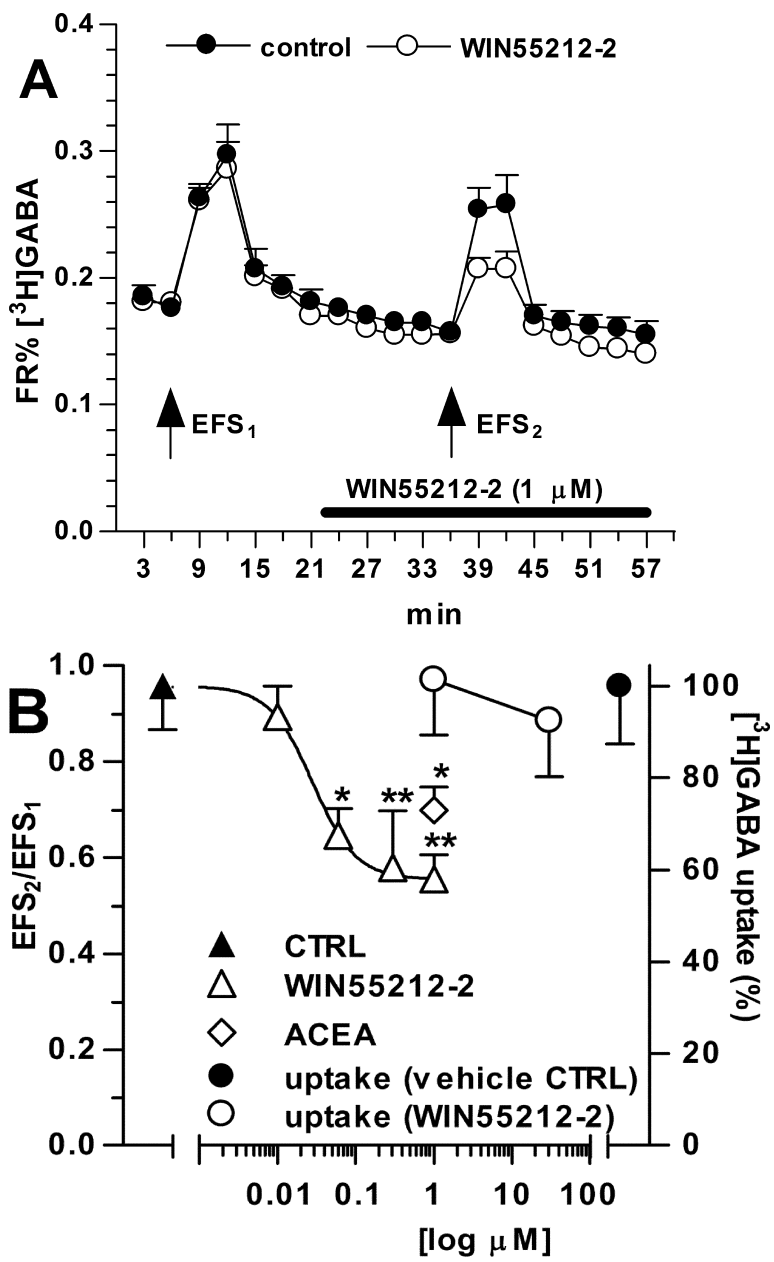

C

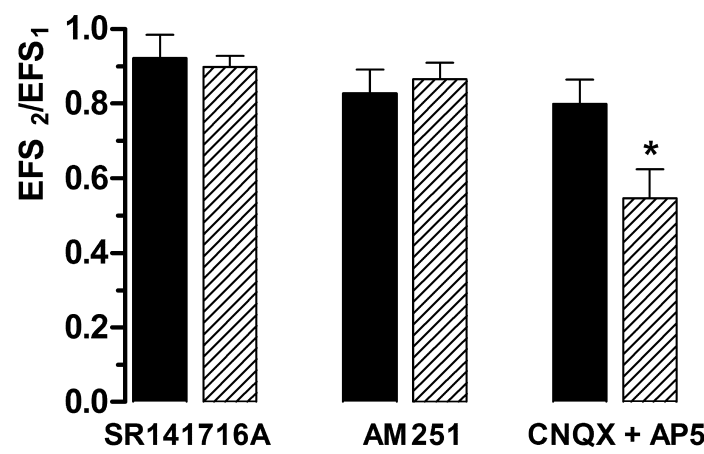

Figure 3. Cannabinoid agonists inhibit the TTX-sensitive, electrically evoked release of $\left[{ }^{3} \mathrm{H}\right] \mathrm{GABA}$ via $\mathrm{CB}_{1}$ receptor activation in rat striatal slices. $A,\left[{ }^{3} \mathrm{H}\right] \mathrm{GABA}$ release from striatal slices in the control condition and in the presence of the nonselective cannabinoid agonist WIN55212-2. After 1 h of washout, 3 min samples were collected, as indicated by the $x$-axis, and counted for tritium. The sample tritium content was expressed as the percentage of the actual tissue tritium content at the time of the sample collection (FR\%). The slices were stimulated twice with a pair of platinum electrodes (at $40 \mathrm{~V}, 2 \mathrm{~Hz}, 1 \mathrm{~ms}, 360$ bipolar, square-wave pulses), as indicated by the arrows (electrical field stimulation, $\mathrm{EFS}_{1}$ and $\mathrm{EFS}_{2}$ ). The nonselective $\mathrm{CB}_{1}$ receptor agonist WIN55212-2 was applied, as indicated by the horizontal bar, 20 min before EFS $_{2}$. WIN55212-2 decreased the second stimulation-evoked release of $\left[{ }^{3} \mathrm{H}\right] \mathrm{GABA}$. $\boldsymbol{B}$, WIN55212-2 concentration dependently attenuated the evoked release of $\left[{ }^{3} \mathrm{H}\right] \mathrm{GABA}$ but did not modify its uptake. $A C E A$, a highly selective $C_{1}$ receptor agonist, tested at $1 \mu \mathrm{m}$, also significantly inhibited the release of $\left[{ }^{3} \mathrm{H}\right] \mathrm{GABA}$. $C$, The effect of WIN55212-2 (expressed with the $\mathrm{EFS}_{2} / \mathrm{EFS}_{1}$ ratio) is prevented by the selective $\mathrm{CB}_{1}$ receptor antagonists SR141716A $(1 \mu \mathrm{M})$ and AM251 $(1 \mu \mathrm{M})$, but not by coapplication of the AMPA/kainate receptor antagonist CNQX (10 $\mu \mathrm{M})$ and the NMDA receptor antagonist AP-5 $(50 \mu \mathrm{M}) .{ }^{*} p<0.05 ;{ }^{* *} p<0.01 . n \geq 8$ for all data points. CTRL, Control. 
The effect of WIN55212-2 ( 1 and $30 \mu \mathrm{M})$ was tested on the uptake of $\left[{ }^{3} \mathrm{H}\right] \mathrm{GABA}$, to determine whether the decrease in the evoked release is attributable to increased uptake. After the 30 min incubation, the tritium uptake into the slices amounted to $27,085 \pm 6741 \mathrm{DPM} / \mathrm{mg}$ tissue [vehicle control (CTRL), $n=10$ ], which was unaltered in the presence of $1 \mu \mathrm{M} \operatorname{WIN} 55212-2(n=6)$ (Fig. 3B). The cannabinoid agonist had no effect on the uptake of $\left[{ }^{3} \mathrm{H}\right] \mathrm{GABA}$ even at $6 \mu \mathrm{M}$ (data not shown) and $30 \mu \mathrm{M}$, which is supramaximal for the $\mathrm{CB}_{1}$ receptor.

$\left[{ }^{3} \mathrm{H}\right] \mathrm{DA}$ release experiments from slices

After the $1 \mathrm{~h}$ washout period, the basal $\left[{ }^{3} \mathrm{H}\right] \mathrm{DA}$ efflux amounted to $0.551 \pm 0.040 \mathrm{FR} \%(n=10)$, similar to that found in our previous study (Milusheva et al., 1996). The same electrical field stimulation parameters were used as to evoke $\left[{ }^{3} \mathrm{H}\right] \mathrm{GABA}$ release. The first stimulation-evoked release $\left(\mathrm{EFS}_{1}\right)$ was $2.794 \pm 0.262$ FR\%, and the $\mathrm{EFS}_{2} / \mathrm{EFS}_{1}$ value was $0.757 \pm 0.061$ (Fig. $4 A-C$ ). WIN55212-2 (0.3-10 $\mu \mathrm{M})$ and CP55940 $(1-10 \mu \mathrm{M})$ did not significantly affect either the resting or the evoked $\left[{ }^{3} \mathrm{H}\right] \mathrm{DA}$ release (Fig. 4A,B). To reveal whether a cannabinoid effect would appear at a different stimulation frequency, we also stimulated the slices at $0.5 \mathrm{~Hz}\left(\mathrm{EFS}_{1}, 2.385 \pm 0.400 ; \mathrm{EFS}_{2} / \mathrm{EFS}_{1}, 0.822 \pm 0.108 ; n=6\right)$ as well as at $10 \mathrm{~Hz}\left(\mathrm{EFS}_{1}, 1.719 \pm 0.266 ; \mathrm{EFS}_{2} / \mathrm{EFS}_{1}, 0.810 \pm\right.$ $0.055 ; n=4)$. WIN55212-2 ( $1 \mu \mathrm{M} ; n=6$ and 4$)$ did not modify the evoked release of $\left[{ }^{3} \mathrm{H}\right] \mathrm{DA}$ at any of the frequencies tested. It is possible that the effect of the cannabinoids was hidden because of simultaneous activation of inhibitory and/or excitatory neurotransmission by field stimulation in the intact slice. Thus, we challenged the $\left[{ }^{3} \mathrm{H}\right]$ DA release with WIN55212-2 $(1 \mu \mathrm{M})$ in the presence of the ionotropic glutamate receptor antagonists AP-5 $(50 \mu \mathrm{M})$ and $\mathrm{CNQX}(10 \mu \mathrm{M})$ and the $\mathrm{GABA}_{\mathrm{A}}$ receptor antagonist bicuculline $(20 \mu \mathrm{M})$. However, no alteration of the evoked and resting $\left[{ }^{3} \mathrm{H}\right] \mathrm{DA}$ release by WIN55212-2 was observed under this condition (Fig. $4 C$ ). $\mathrm{CB}_{1}$ receptor activation may lead to the production of nitric oxide (for review, see Howlett and Mukhopadhyay, 2000), which can interact with the release of dopamine in the striatum (Kiss et al., 2004). However, WIN55212-2 (1 $\mu \mathrm{M})$ had no effect on the release of dopamine in the presence of $\mathrm{N}-\omega$ nitro-L-arginine methyl ester (L-NAME) $(100 \mu \mathrm{M})$, the watersoluble nitric oxide synthase inhibitor (Fig. $4 C$ ).

$\mathrm{D}_{2}$ and $\mathrm{CB}_{1}$ receptors can form heterodimers. Coactivation of this chimeric receptor by cannabinoids and dopamine increases cAMP accumulation (Glass and Felder, 1997; Jarrahian et al., 2004). This could also mask an inhibitory response mediated by lone $\mathrm{CB}_{1}$ receptors. But WIN55212-2 (1 $\left.\mu \mathrm{M}\right)$ did not change the evoked or resting $\left[{ }^{3} \mathrm{H}\right] \mathrm{DA}$ release in the presence of the $\mathrm{D}_{2}$ receptor antagonist sulpiride $(3 \mu \mathrm{M})$ (Fig. $4 C)$. Next, we tested whether the $\mathrm{CB}_{1}$ receptors were already active (by constitutive activity or by endocannabinoids). The $\mathrm{CB}_{1}$-selective antagonist SR141716A (at $10 \mu \mathrm{M}$, a concentration supramaximal to antagonize the $\mathrm{CB}_{1}$ receptors), introduced after the first stimulation, altered neither the resting nor the evoked release of dopamine (Fig. 4C). Finally, WIN55212-2 at $6 \mu \mathrm{M}$ did not modify the uptake of dopamine, which amounted to $15,776 \pm 4745 \mathrm{DPM} / \mathrm{mg}$ tissue (vehicle CTRL, $n=6$ ) (Fig. $4 B$ ). Thus, the lack of change in dopamine release could not have been caused by simultaneous reductions in uptake and release.

\section{$\left[{ }^{3} \mathrm{H}\right]$ Glutamate release experiments from rat striatal synaptosomes}

Because astrocytes are equipped with cannabinoid receptors (Di Marzo et al., 2002) and can take up and calcium dependently release glutamate (for review, see Nishizaki, 2004), we performed
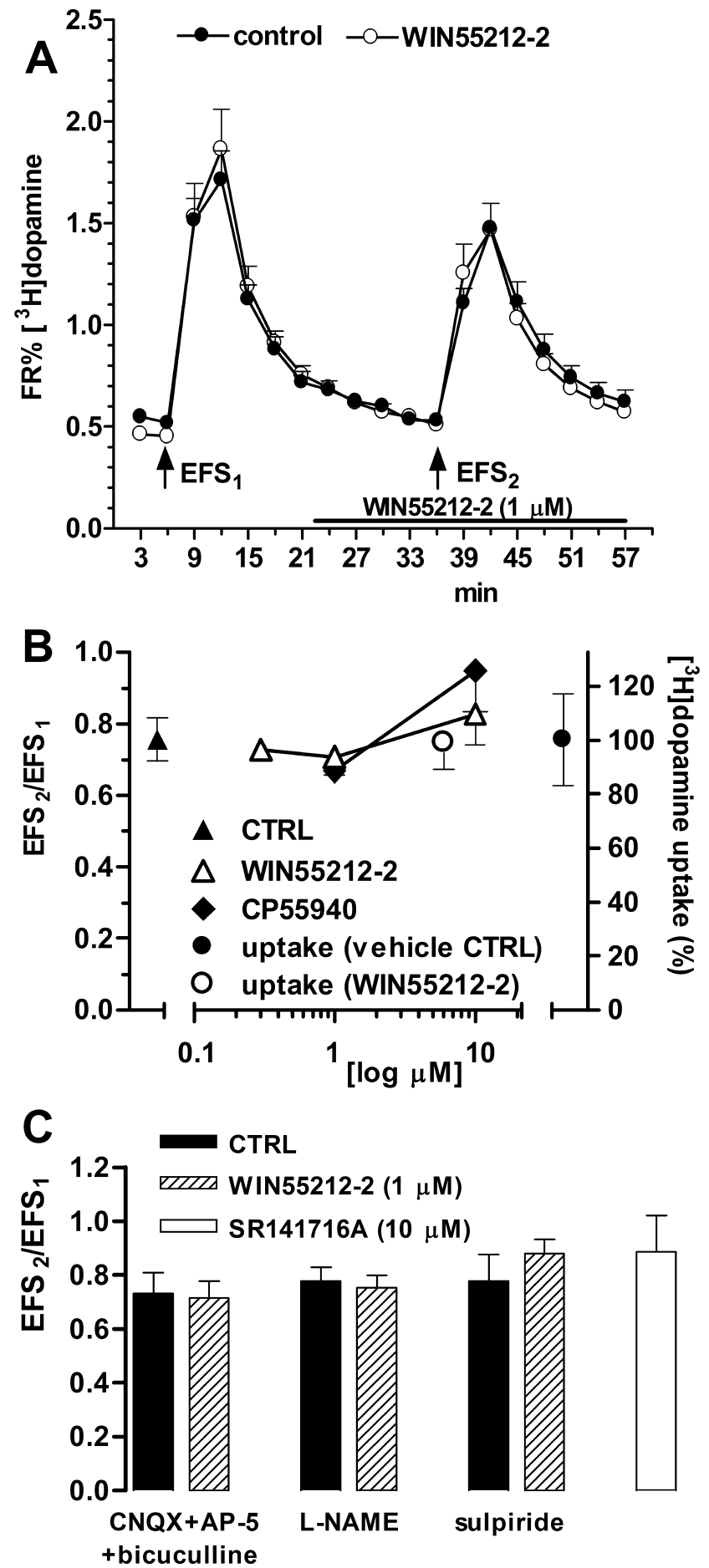

Figure 4. Cannabinoids do not affect the TTX-sensitive, electrical field stimulation-evoked release and uptake of $\left[{ }^{3} \mathrm{H}\right] \mathrm{DA}$ in rat striatal slices. $\boldsymbol{A}, \boldsymbol{B}$, Neither WIN55212-2 nor CP55940 modulated the basal outflow or evoked release of $\left[{ }^{3} \mathrm{H}\right] \mathrm{BA}$ nor the uptake of $\left[{ }^{3} \mathrm{H}\right] \mathrm{DA}$ under experimental conditions similar to those used for $\left[{ }^{3} \mathrm{H}\right] \mathrm{GABA}$ (see Fig. $3 A, B$ ). Note that WIN55212-2 also did not affect release if the frequency of stimulation was four times lower or five times higher (see Results). C, The lack of modulation by WIN55212-2 (expressed with the $\mathrm{EFS}_{2} / \mathrm{EFS}_{1}$ ratio) is not attributable to the presence of facilitatory or inhibitory polysynaptic mechanisms, because the blockade of ionotropic glutamate receptors by CNQX (10 $\mu \mathrm{M})$ and AP-5 $(50 \mu \mathrm{M})$ and by the $\mathrm{GABA}_{\mathrm{A}}$ antagonist bicuculline $(20 \mu \mathrm{M})$, respectively, did not reveal any WIN55212-2-mediated modulation, nor did the blockade of nitric oxide synthase by L-NAME $(100 \mu \mathrm{M})$. Activation of $\mathrm{CB}_{1}$ receptors by endogenous cannabinoids does not explain the lack of WIN55212-2 effect because the selective $C_{1}$ receptor antagonist SR141716A (10 $\left.\mu \mathrm{m}\right)$ applied 20 min before $\mathrm{EFS}_{2}$ had no effect on the second stimulation-evoked release of $\left[{ }^{3} \mathrm{H}\right] \mathrm{DA} . n \geq 6$ for all data points. CTRL, Control. 
the following experiments in separated nerve terminals. This protocol allowed us to selectively investigate the presynaptic effects in the absence of extrasynaptic and glia mechanisms.

The basal $\left[{ }^{3} \mathrm{H}\right]$ glutamate release amounted to $7.19 \pm 0.39 \mathrm{FR} \%$ (CTRL, $n=$ $16)$, the $\left[{ }^{3} \mathrm{H}\right]$ glutamate efflux evoked by the first $\mathrm{K}^{+}$depolarization $\left(\mathrm{S}_{\mathrm{K} 1}\right)$ was $8.50 \pm 0.59 \mathrm{FR} \%$, and the $\mathrm{S}_{\mathrm{K} 2} / \mathrm{S}_{\mathrm{K} 1}$ value was $0.823 \pm 0.049$, data similar to that obtained in the hippocampus (Köfalvi et al., 2003) (Fig. 5A-C). The nonselective cannabinoid agonists CP55940 (0.1-10 $\mu \mathrm{M}$; $\mathrm{EC}_{50}, 0.58 \mu \mathrm{M}$; maximal effect, $40.2 \%$ inhibition), $\Delta^{9}$-THC (1-30 $\mu \mathrm{M} ; 1.46 \mu \mathrm{M}$; 25.2\%), and WIN55212-2 (0.3-30 $\mu \mathrm{M}$; $3.38 \mu \mathrm{M} ; 53.7 \%)$ concentration dependently attenuated the $25 \mathrm{mM} \mathrm{K}^{+}$-evoked $\left[{ }^{3} \mathrm{H}\right]$ glutamate release $(n=4-6)$ (Fig. $5 A-C)$. It is noteworthy that WIN55212-3, the enantiomer of WIN55212-2 being inactive at the $\mathrm{CB}_{1}$ receptor, had no significant effect $(n=4)$ (Fig. $5 B)$. This enantiomer was applied at $6 \mu \mathrm{M}$, at which the original compound exerted maximal inhibition. In our previous study (Köfalvi et al., 2003), we found concentration-dependent inhibition of the $25 \mathrm{mM} \mathrm{K}^{+}$-evoked [ ${ }^{3} \mathrm{H}$ ] glutamate release by SR141716A, the $\mathrm{CB}_{1}$-selective antagonist in the hippocampus. A similar inhibition also occurs in striatal synaptosomes (0.6-30 $\mu \mathrm{M} ; \mathrm{EC}_{50}, 3.01 \mu \mathrm{M}$; maximal effect, $45.9 \%)$. In addition, a structurally related $\mathrm{CB}_{1}$ antagonist, $\mathrm{AM} 251\left(0.6-30 \mu \mathrm{M} ; \mathrm{EC}_{50}\right.$, $3.94 \mu \mathrm{M}$; maximal effect, 57.0\%), also decreases glutamate release (Fig. $5 B$ ). This effect, which is unique for the release of glutamate, makes the antagonists as potent and effective glutamate release inhibitors as WIN55212-2, the agonist.

Next, we tested the effect of WIN55212-2 and CP55940 at the concentrations that had evoked the maximal effect, in the presence of SR141716A and AM251, the $\mathrm{CB}_{1}$-selective antagonists, at a concentration that did not decrease glutamate release $(1 \mu \mathrm{M})$. SR141716A partially reversed the inhibition of CP55940 (3 $\mu \mathrm{M})$ and of WIN55212-2 (6 $\mu \mathrm{M})$, but the effect of agonists remained significant. However, their effects on the evoked release were completely prevented by AM251 (Fig. 5C).

WIN55212-2 and AM251 at the low micromolar range inhibit veratridine (i.e., sodium channel activation)-evoked glutamate release from whole-brain synaptosomes by direct, competitive blockade of voltage-dependent $\mathrm{Na}^{+}$channels (Nicholson et al., 2003; Liao et al., 2004). In our model, as expected, the $25 \mathrm{mM} \mathrm{K}^{+}$-evoked $\left[{ }^{3} \mathrm{H}\right]$ glutamate release was not TTX $(1 \mu \mathrm{M})$ (i.e., voltage-gated sodium channel) dependent (Fig. 5C); therefore, the effect of the cannabinoid ligands was independent of sodium channel blockade.

WIN55212-2 slightly but concentration dependently attenuated the resting $\left[{ }^{3} \mathrm{H}\right.$ ] glutamate outflow, with a maximal effect of $24 \%$ at $6 \mu \mathrm{M}(n=6 ; p<0.05)$ (Fig. $5 A)$. The same was observed with CP55940 (21\% at $10 \mu \mathrm{M} ; n=6 ; p<0.05)$, whereas $\Delta^{9}$-THC was devoid of any effect on the resting $\left[{ }^{3} \mathrm{H}\right]$ glutamate outflow at the concentrations tested. This suggests that some cannabinoid ligands might affect glutamate transporters independently of ac- tivation of the $\mathrm{CB}_{1}$ receptor. To test this hypothesis, we challenged the uptake of glutamate by WIN55212-2. The $\left[{ }^{3} \mathrm{H}\right]$ glutamate uptake into striatal synaptosomes amounted to $571,127 \pm$ $9282 \mathrm{DPM} / 50 \mu \mathrm{l}(\sim 340 \mu \mathrm{g}$ of protein; $n=24)$. WIN55212-2 $(6 \mu \mathrm{M})$ concentration dependently attenuated the uptake of $\left[{ }^{3} \mathrm{H}\right]$ glutamate with the $\mathrm{EC}_{50}$ value of $2.62 \mu \mathrm{M}$ (Fig. $5 D$ ). SR141716A $(1 \mu \mathrm{M})$ alone had no significant effect on the uptake and did not reverse the uptake inhibitory action of WIN55212-2 (Fig. 5D). AM251 concentration dependently attenuated the uptake of $\left[{ }^{3} \mathrm{H}\right]$ glutamate, and again $1 \mu \mathrm{M}$ AM251 fully prevented the effect of WIN55212-2. WIN55212-3, the enantiomer of WIN55212-2 inactive at the $\mathrm{CB}_{1}$ receptor, had the same efficacy to attenuate $\left[{ }^{3} \mathrm{H}\right]$ glutamate uptake (i.e., the action of cannabinoids on $\left[{ }^{3} \mathrm{H}\right]$ glutamate uptake might not be $\mathrm{CB}_{1}$ receptor mediated) (Fig. $5 D$ ).

Localization of $\mathrm{CB}_{1}$ receptor expression on glutamatergic nerve terminals of wild-type mouse striatum

Because the pharmacological profile of the cannabinoid receptor underlying the attenuation of glutamate efflux was not entirely identical to that responsible for the reduction of $\left[{ }^{3} \mathrm{H}\right] \mathrm{GABA}$ release, we also explored the localization and function of $\mathrm{CB}_{1}$ receptors in striatal nerve terminals of wild-type and $\mathrm{CB}_{1}-/-$ mice. Overall, 1684 immunopositive nerve terminals from three wild-type animals, littermates of the $\mathrm{CB}_{1}-/-$ mice, were counted. Interestingly, $78.8 \pm$ $8.5 \%$ of VGLUT-1- and VGLUT-2-positive nerve terminals were 

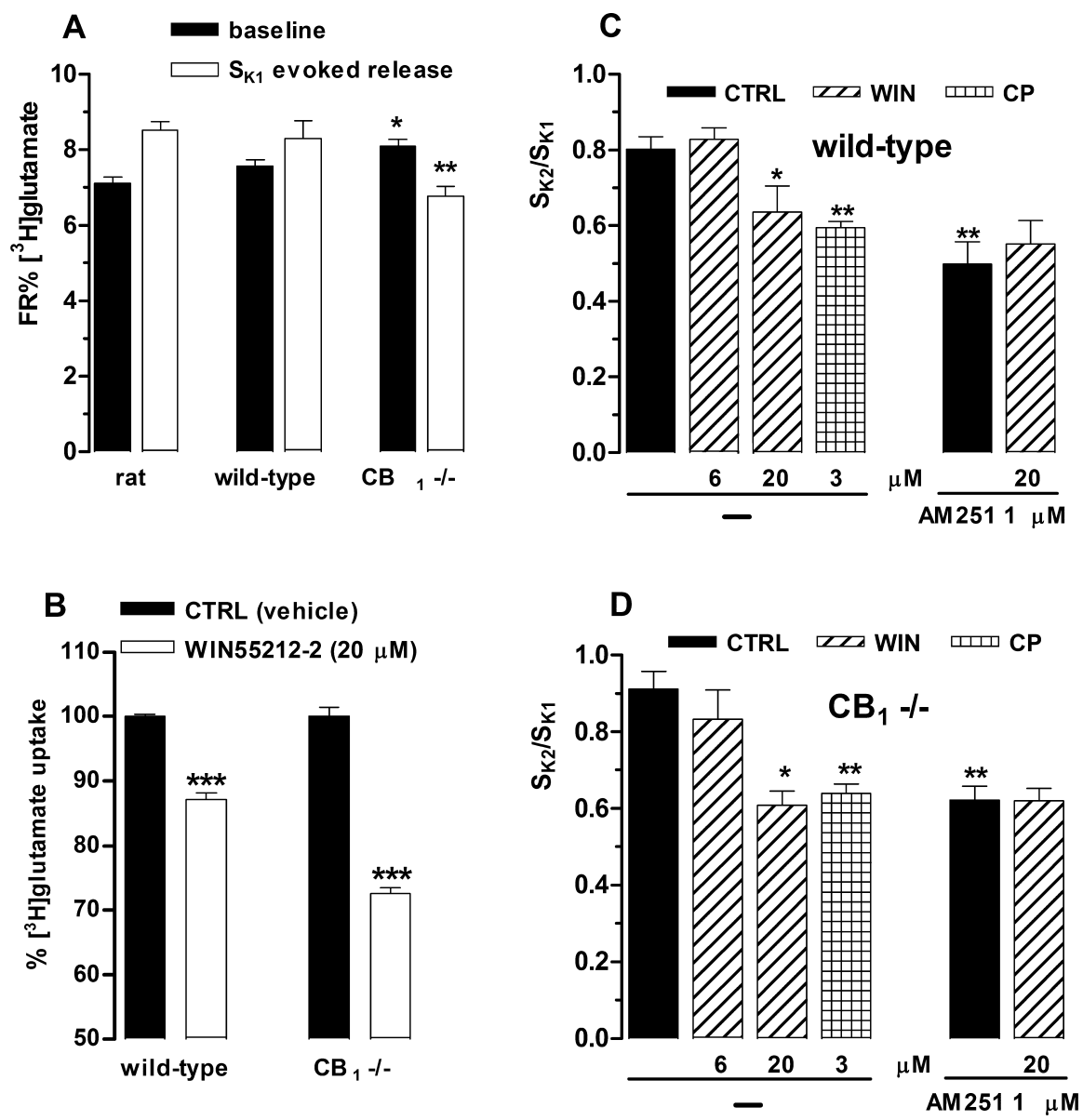

Figure 6. Modulation of the uptake and release of $\left[{ }^{3} \mathrm{H}\right]$ glutamate in striatal synaptosomes of wild-type and $\mathrm{CB}_{1}$ receptor knock-out $(-/-)$ mice. $A$, Properties of $\left[{ }^{3} \mathrm{H}\right]$ glutamate release in the rat and the two mouse types. The release is slightly but significantly altered in the $\mathrm{CB}_{1}-/-$ mouse compared with the wild-type mouse. $\boldsymbol{B}$, WIN55212-2 inhibits the uptake of [ $\left.{ }^{3} \mathrm{H}\right] \mathrm{glu}$ tamate in both mouse types. C, D, WIN55212-2 (although less potently and effectively) and (P55940 attenuate the Ca ${ }^{2+}$ dependent, $25 \mathrm{~mm} \mathrm{~K}{ }^{+}$-evoked release of $\left[{ }^{3} \mathrm{H}\right]$ glutamate from the wild-type $C D-1$ and the $\mathrm{CB}_{1}$ null-mutant mouse striatal synaptosomes. In the presence of $A M 251$, given 20 min before $S_{K 1}$ and being present in all solutions used, the $S_{K 2} / S_{K 1}$ ratio significantly diminished, indicating differences between the $C D-1$ mouse and the Wistar rat, although the likely time-dependent underlying mechanism is unclear. No further inhibition of $\left[{ }^{3} \mathrm{H}\right]$ glutamate release by WIN55212-2 $(20 \mu \mathrm{m})$ is observed in the presence of AM251 either in wild-type or CB1 - /- mice. ${ }^{*} p<0.05 ;{ }^{* *} p<0.01$; ${ }^{* *} p<0.001$ versus drug-free controls (CTRL). $n \geq 8$ for all data points.

Table 1. Effect of cannabinoid ligands on the uptake $(U)$ and the stimulationevoked release (ER) of $\left[{ }^{3} \mathrm{H}\right]$ glutamate from striatal synaptosomes tested in different animal species

\begin{tabular}{lllc}
\hline Treatments & Species & $\mathrm{U}$ & ER \\
\hline WIN55212-2 & R, WT & $\downarrow$ & $\downarrow$ \\
WIN55212-3 & $\mathrm{R}$ & $\downarrow$ & $\rightarrow$ \\
WIN55212-2 plus SR141716A & $\mathrm{R}$ & $\downarrow / \rightarrow$ & $\downarrow / \rightarrow$ \\
WIN55212-2 plus AM251 & $\mathrm{R}$, WT & $\rightarrow$ & $\rightarrow$ \\
SR141716A & $\mathrm{R}$ & $\rightarrow$ & $\downarrow$ \\
AM251 & $\mathrm{R}$ & $\downarrow$ & $\downarrow$ \\
WIN55212-2 & K0 & $\downarrow$ & $\downarrow$ \\
WIN55212-2 plus AM251 & K0 & $\rightarrow$ & $\rightarrow$ \\
\hline
\end{tabular}

R, Rat; WT, wild-type mouse; $K 0, \mathrm{CB}_{1}-/-$ mouse.

endowed with $\mathrm{CB}_{1}$ immunoreactivity, indicating an $\sim 40 \%$ greater colocalization than in the rat (Fig. $2 A, B$ ).

$\left[{ }^{3} \mathrm{H}\right]$ Glutamate release experiments from wild-type and $\mathrm{CB}_{1}$ homozygote null-mutant mouse striatal synaptosomes The basal and $25 \mathrm{~mm} \mathrm{~K}^{+}$-evoked $\left[{ }^{3} \mathrm{H}\right]$ glutamate release from the striatal synaptosomes of the rat and wild-type and $\mathrm{CB}_{1}-/-$ mice is illustrated in Figure 6A. Although the resting and evoked $\left[{ }^{3} \mathrm{H}\right]$ glutamate efflux were similar in the rat and in the wild-type mouse, the basal release was slightly and significantly higher, whereas the evoked release was slightly and significantly lower in the $\mathrm{CB}_{1}-/-$ mouse. Interestingly, WIN55212-2 appeared to be less potent and efficacious to inhibit the release of $\left[{ }^{3} \mathrm{H}\right]$ glutamate in the wild-type mice (Fig. $6 C)$ than in the rat striatum or in the mouse hippocampus (Köfalvi et al., 2003). In contrast, CP55940 inhibited the evoked release by $26 \%$ already at $3 \mu \mathrm{M}$. AM251 (1 $\mu \mathrm{M}$ ) applied $20 \mathrm{~min}$ before the first stimulation significantly decreased the $\mathrm{S}_{\mathrm{K} 2} / \mathrm{S}_{\mathrm{K} 1}$ ratio in wild-type mice, and in the presence of AM251, WIN55212-2 (20 $\mu \mathrm{M})$ did not further inhibit the evoked release of $\left[{ }^{3} \mathrm{H}\right]$ glutamate (Fig. 6C). Nevertheless, the inhibitory effect of both cannabinoid agonists, as well as that of AM251, persisted in the $\mathrm{CB}_{1}-/-$ mouse (Fig. 6D). Furthermore, AM251 occluded the effect of WIN55212-2 in the $\mathrm{CB}_{1}$ receptor knock-out mice. This is in contrast to the hippocampus, where another $\mathrm{CB}_{1}$ receptor-selective antagonist, SR141716A, applied at 1-5 $\mu \mathrm{M}$ did not prevent the inhibition produced by agonists (Köfalvi et al., 2003). WIN55212-2 (20 $\mu \mathrm{M}$; $24 \% ; n=6 ; p<0.01)$ and CP55940 (3 $\mu \mathrm{M}$; $17 \% ; n=6 ; p<0.01)$ also significantly inhibited the basal release of $\left[{ }^{3} \mathrm{H}\right]$ glutamate in the $\mathrm{CB}_{1}$ null-mutant mouse. WIN55212-2 $(20 \mu \mathrm{M})$ strongly and significantly inhibited the uptake of $\left[{ }^{3} \mathrm{H}\right]$ glutamate in both mouse types (Fig. $6 \mathrm{~B}$ ). For the sake of comprehension, the effect of cannabinoid agonists and antagonists on the uptake and the stimulation-evoked release of $\left[{ }^{3} \mathrm{H}\right]$ glutamate is summarized in Table 1.

\section{Discussion}

Activation of $\mathrm{CB}_{1}$ receptors attenuates neuronal activity by presynaptic inhibition of neurotransmitter release and postsynaptic hyperpolarization (for review, see Freund et al., 2003). We now used a highly sensitive immunochemical method that allows determining the quantitative distribution of $\mathrm{CB}_{1}$ receptors among subsynaptic elements in isolated nerve terminals. Our novel finding (i.e., the localization of $\mathrm{CB}_{1}$ receptors in the presynaptic active zone) facilitates our understanding of how $\mathrm{CB}_{1}$ receptors likely attenuate neurotransmitter release via inhibition of active zone molecular targets (i.e., of $\mathrm{N}$ - and P-type calcium channels and release machinery functions) (for review, see Jarvis and Zamponi, 2001). The $\mathrm{CB}_{1}$ receptor immunoreactivity, found extrasynaptically, which may indicate recycling and/or newly synthesized pools of the $\mathrm{CB}_{1}$ receptors, is concordant with our previous electron microscopy findings in the hippocampus, where presynaptic $\mathrm{CB}_{1}$ receptors were found primarily in extrasynaptic membranes of GABAergic boutons (Katona et al., 1999, 2000). In the present study, receptors in the extrasynaptic fraction may comprise postsynaptic receptors outside the postsynaptic density as well, and we found $\mathrm{CB}_{1}$ receptors also in the postsynaptic density. The presence of postsynaptic $\mathrm{CB}_{1}$ receptors, which may 
control the excitability of the dendrites, is consistent with a previous immunocytochemical observation in the striatum (Rodríguez et al., 2001) and other functional data (Childers and Deadwyler, 1996; Bacci et al., 2004). Together, the distribution of $\mathrm{CB}_{1}$ receptors in the striatum is similar to that of hippocampal $\mathrm{A}_{1}$ adenosine receptors, which were found in all subsynaptic fractions, although strategically in the active zone (Rebola et al., 2003).

\section{Modulation of GABAergic transmission}

Our present finding (i.e., the widespread $\mathrm{CB}_{1}$ receptor expression in GABAergic terminals) is in agreement with previous reports (Herkenham et al., 1990, 1991; Mailleux and Vanderhaeghen, 1992; Fusco et al., 2004). WIN55212-2 inhibited the evoked release of $\left[{ }^{3} \mathrm{H}\right] \mathrm{GABA}$ with a potency and efficacy similar to those of our and others' previous findings in the hippocampus and striatum (Katona et al., 1999, 2000; Szabo et al., 1998). Moreover, ACEA, a selective $\mathrm{CB}_{1}$ receptor agonist, also significantly inhibited the release of GABA. The effect of WIN55212-2 was completely prevented by the $\mathrm{CB}_{1}$-selective antagonists AM251 and SR141716A. Similar to the hippocampus (Katona et al., 1999, 2000), the inhibition of GABA release was not attributable to a decrease in the excitatory inputs or to an increase in reuptake. Thus, nanomolar concentrations of cannabinoid agonists inhibit the release of GABA with a pharmacological profile fully consistent with the activation of $\mathrm{CB}_{1}$ receptors, regardless of the brain area (striatum vs hippocampus), ligands (e.g., SR141716A, AM251), and techniques (neurochemistry vs electrophysiology) used.

\section{Modulation of dopaminergic transmission}

Our present study allowed a direct visualization of $\mathrm{CB}_{1}$ receptors for the first time on catecholaminergic terminals in the striatum. Only a small percentage of these terminals were endowed with $\mathrm{CB}_{1}$ receptors, which corresponds to the minor expression of $\mathrm{CB}_{1}$ receptor mRNA in the substantia nigra (Julian et al., 2003) and other dopaminergic nuclei (Matsuda et al., 1993) and suggests that cannabinoids might not modulate dopamine release directly. Accordingly, WIN55212-2 and CP55940 failed to modify the release or uptake of dopamine, even when GABAergic, glutamatergic, dopaminergic, nitrergic, and endogenous cannabinergic inputs were excluded. These data are in concordance with the results obtained by measuring endogenous dopamine levels (Szabo et al., 1999; de Lago et al., 2004). Together, these observations do not support a major role for direct cannabinoid control of striatal dopamine release (van der Stelt and Di Marzo, 2003).

\section{Modulation of glutamatergic transmission}

We visualized a strong $\mathrm{CB}_{1}$ receptor expression in glutamatergic terminals, colabeled for VGLUT-1 and VGLUT-2, in the rat and mouse striatum. WIN55212-2 and CP55940 attenuated the basal $\left[{ }^{3} \mathrm{H}\right]$ glutamate outflow, thought to occur mainly via membrane transporters. WIN55212-2, WIN55212-3, and AM251, but not SR141716A, also inhibited $\left[{ }^{3} \mathrm{H}\right]$ glutamate uptake, even in the $\mathrm{CB}_{1}-/-$ mouse. The possible underlying mechanisms are detailed in supplemental Figure 1 (available at www.jneurosci.org as supplemental material).

We also showed that cannabinoid ligands concentration dependently inhibited $\mathrm{K}^{+}$-evoked, $\mathrm{Ca}^{2+}$-dependent $\left[{ }^{3} \mathrm{H}\right]$ glutamate release. Electrophysiological recordings in the striatum have recently delineated a presynaptic inhibition of excitatory transmission by cannabinoids at a low micromolar range (Gerdeman and Lovinger, 2001; Huang et al., 2001; Gerdeman et al., 2002; Brown et al., 2003; Ronesi et al., 2004). The potency of
WIN55212-2 and $\Delta^{9}$-THC were similar to those in our present study and to the $\mathrm{EC}_{50}$ value of WIN55212-2 in our previous study in the hippocampus $(3.47 \mu \mathrm{M})$. Furthermore, the effect of WIN55212-2 and CP55940 was prevented by the $\mathrm{CB}_{1}$ antagonist AM251 (1 $\mu \mathrm{M})$, whereas the $\mathrm{CB}_{1}$-inactive enantiomer WIN55212-3 had no effect. Together, these results suggest that presynaptic $\mathrm{CB}_{1}$ receptor activation inhibits $\mathrm{Ca}^{2+}$-dependent glutamate release in rat striatal synaptosomes.

On the other hand, a part of our present findings, in particular the persisting inhibitory effect of WIN55212-2 and CP55940 in the $\mathrm{CB}_{1}-/-$ mice, cannot be explained by the exclusive activation of $\mathrm{CB}_{1}$ receptors in the striatum. Indeed, cannabinoids were shown to interact with other targets to inhibit transmitter release (for review, see Di Marzo et al., 2002; De Petrocellis et al., 2004; Pertwee, 2004). SR141716A is known to block voltage-dependent $\mathrm{Ca}^{2+}$ channels and $\mathrm{K}_{\mathrm{Ca}}$ channels $\left(\mathrm{EC}_{50}, \approx 3-5 \mu \mathrm{M}\right.$ ) (Shen and Thayer, 1998; White and Hiley, 1998; Bukoski et al., 2002). This can explain the inhibitory action of SR141716A and its structural analog AM251 on the $\mathrm{K}^{+}$-evoked, $\mathrm{Ca}^{2+}$-dependent $\left[{ }^{3} \mathrm{H}\right]$ glutamate release but not that of WIN55212-2, which stereoselectively inhibited glutamate release although it does not stereoselectively inhibit $\mathrm{Ca}^{2+}$ channels. Importantly, WIN55212-2 and AM251 were recently shown to block sodium channels (Liao et al., 2004; Nicholson et al., 2003). However, in our model, $\mathrm{K}^{+}$-evoked $\left[{ }^{3} \mathrm{H}\right]$ glutamate release is TTX insensitive (i.e., the activity of sodium channels does not contribute to $\left[{ }^{3} \mathrm{H}\right]$ glutamate release) (Fig. 5C), therefore the effect of WIN55212-2 cannot be explained by sodium channel blockade either. Conversely, the finding that AM251 prevented the effect of cannabinoids in the $\mathrm{CB}_{1}$ $-I-$ mice is a clear indication for the involvement of a non- $\mathrm{CB}_{1}$ cannabinoid receptor. However, the pharmacological phenotype of this non- $\mathrm{CB}_{1}$ receptor seems to be very similar to the classical $\mathrm{CB}_{1}$ receptor; therefore, we call it " $\mathrm{CB}_{1}$-like" receptor. Hence, although both SR141716A and AM251 are known as selective $\mathrm{CB}_{1}$ receptor antagonists, their selectivity toward a yet unknown and uncloned receptor cannot be determined. For similar reasons, it is difficult to determine the exact contribution of $\mathrm{CB}_{1}$ and $\mathrm{CB}_{1}$-like receptors in the rat and wild-type mice.

The question arises whether this $\mathrm{CB}_{1}$-like receptor is identical to the putative non- $\mathrm{CB}_{1}$ cannabinoid receptors demonstrated in other studies using $\mathrm{CB}_{1}-/-$ mouse. WIN55212-2 and anandamide in the low micromolar range inhibit glutamate release in the hippocampus of $\mathrm{CB}_{1}-/-$ mouse (Hájos et al., 2001; Hájos and Freund, 2002a,b; Köfalvi et al., 2003); however, these actions were insensitive to AM251, opposite from our study. WIN55212-2 and anandamide, but not CP55940, stimulate $\left[{ }^{35} \mathrm{~S}\right] \mathrm{GTP} \gamma \mathrm{S}$ binding in the whole-brain and cerebellar membranes (Di Marzo et al., 2000b; Breivogel et al., 2001; Monory et al., 2002) but not in the basal ganglia (Breivogel et al., 2001; Monory et al., 2002) of $\mathrm{CB}_{1}-/-$ mice; therefore, this pathway is also unlikely to mediate the actions described in our study. On the other hand, the identity of the $\mathrm{CB}_{1}$-like receptor with those non- $\mathrm{CB}_{1}$, non- $\mathrm{VR}_{1}$ receptors that were shown to mediate the motor depressant effect of anandamide and other vanillyl compounds (Di Marzo et al., 2000a,b) is still an open possibility, which needs additional investigation. Presumably, this $\mathrm{CB}_{1}$-like receptor functions regardless of the presence of $\mathrm{CB}_{1}$ receptors in glutamatergic nerve terminals and can fully compensate the lack of $\mathrm{CB}_{1}$ receptors in the $\mathrm{CB}_{1}-/-$ mice, perhaps via developmental upregulation. This idea is also supported by the fact that $\Delta^{9}$ THC, which failed to affect locomotor activity in the $\mathrm{CB}_{1}-1-$ mouse (Di Marzo et al., 2000b), was less efficacious in our study, possibly because it activates mostly $\mathrm{CB}_{1}$ receptors. 
Endocannabinoid levels and $\mathrm{CB}_{1}$ receptor expression are altered in animal models and patients of Huntington's and Parkinson's diseases (for review, see van der Stelt and Di Marzo, 2003). This illustrates the therapeutic potential of the striatal endocannabinoid system modulation. Opposite from other previous findings (Sieradzan et al., 2001; Ferrer et al., 2003), a recent study with cannabis $\left(\Delta^{9}\right.$-THC) did not reveal alteration of akinesia in parkinsonian patients (Carroll et al., 2004). Thus, it is possible that a $\mathrm{CB}_{1}$-like rather than the $\mathrm{CB}_{1}$ receptor (presumably the only receptor of the two that $\Delta^{9}$-THC activates) is responsible for the beneficial effects of other cannabinoids in Parkinson's disease. On the other hand, the therapeutic value of $\mathrm{CB}_{1}$ receptor antagonists in Huntington's disease (van der Stelt and Di Marzo, 2003) can be better explained by the findings of our study (i.e., by the simultaneous facilitation of GABAergic transmission and $\mathrm{CB}_{1}$ receptor-independent inhibition of glutamate release that could brake the glutamatergic excitotoxicity).

In summary, cannabinoids can modulate motor function via direct inhibition of striatal GABA and glutamate release. Moreover, the demonstration of a pharmacologically fully $\mathrm{CB}_{1}$-like effect in the $\mathrm{CB}_{1}-/-$ mice indicates that the conventional cannabinoid ligands, routinely used to identify $\mathrm{CB}_{1}$ receptors, might be inadequate and should provoke a systemic reevaluation using $\mathrm{CB}_{1}$-deficient mice of previous results based solely on the pharmacological identification of the $\mathrm{CB}_{1}$ receptor.

\section{References}

Bacci A, Huguenard JR, Prince DA (2004) Long-lasting self-inhibition of neocortical interneurons mediated by endocannabinoids. Nature 431:312-316.

Breivogel CS, Griffin G, Di Marzo V, Martin BR (2001) Evidence for a new $\mathrm{G}$ protein-coupled cannabinoid receptor in mouse brain. Mol Pharmacol 60:155-163.

Brotchie JM (2003) $\mathrm{CB}_{1}$ cannabinoid receptor signaling in Parkinson's disease. Curr Opin Pharmacol 3:54-61.

Brown TM, Brotchie JM, Fitzjohn SM (2003) Cannabinoids decrease corticostriatal synaptic transmission via an effect on glutamate uptake. J Neurosci 23:11073-11077.

Bukoski RD, Bátkai S, Járai Z, Wang Y, Offertaler L, Jackson WF, Kunos G (2002) $\mathrm{CB}_{1}$ receptor antagonist SR141716A inhibits $\mathrm{Ca}^{2+}$-induced relaxation in $\mathrm{CB}_{1}$ receptor-deficient mice. Hypertension 39:251-257.

Carroll CB, Bain PG, Teare L, Liu X, Joint C, Wroath C, Parkin SG, Fox P, Wright D, Hobart J, Zajicek JP (2004) Cannabis for dyskinesia in Parkinson disease: a randomized double-blind crossover study. Neurology 63:1245-1250.

Childers SR, Deadwyler SA (1996) Role of cyclic AMP in the actions of cannabinoid receptors. Biochem Pharmacol 52:819-827.

Compton DR, Aceto MD, Lowe J, Martin BR (1996) In vivo characterization of a specific cannabinoid receptor antagonist (SR141716A): inhibition of delta 9-tetrahydrocannabinol-induced responses and apparent agonist activity. J Pharmacol Exp Ther 277:586-594.

Cunha RA, Ribeiro JA (2000) Purinergic modulation of [ $\left.{ }^{3} \mathrm{H}\right]$ GABA release from rat hippocampal nerve terminals. Neuropharmacology 39:1156-1167.

de Lago E, de Miguel R, Lastres-Becker I, Ramos JA, Fernandez-Ruiz J (2004) Involvement of vanilloid-like receptors in the effects of anandamide on motor behavior and nigrostriatal dopaminergic activity: in vivo and in vitro evidence. Brain Res 1007:152-159.

De Petrocellis L, Cascio MG, Di Marzo V (2004) The endocannabinoid system: a general view and latest additions. Br J Pharmacol 141:765-774.

Díaz-Hernandez M, Pereira MF, Pintor J, Cunha RA, Ribeiro JA, MirasPortugal MT (2002) Modulation of the rat hippocampal dinucleotide receptor by adenosine receptor activation. J Pharmacol Exp Ther 301:441-450.

Di Marzo V, Breivogel C, Bisogno T, Melck D, Patrick G, Tao Q, Szállási A, Razdan RK, Martin BR (2000a) Neurobehavioral activity in mice of $\mathrm{N}$-vanillyl-arachidonyl-amide. Eur J Pharmacol 406:363-374.

Di Marzo V, Breivogel CS, Tao Q, Bridgen DT, Razdan RK, Zimmer AM, Zimmer A, Martin BR (2000b) Levels, metabolism, and pharmacologi- cal activity of anandamide in $\mathrm{CB}_{1}$ cannabinoid receptor knockout mice: evidence for non- $\mathrm{CB}_{1}$, non- $\mathrm{CB}_{2}$ receptor-mediated actions of anandamide in mouse brain. J Neurochem 75:2434-2444.

Di Marzo V, Hill MP, Bisogno T, Crossman AR, Brotchie JM (2000c) Enhanced levels of endogenous cannabinoids in the globus pallidus are associated with a reduction in movement in an animal model of Parkinson's disease. FASEB J 14:1432-1438.

Di Marzo V, De Petrocellis L, Fezza F, Ligresti A, Bisogno T (2002) Anandamide receptors. Prostaglandins Leukot Essent Fat Acids 66:377-391.

Di Marzo V, Bifulco M, De Petrocellis L (2004) The endocannabinoid system and its therapeutic exploitation. Nat Rev Drug Discov 3:771-784.

Ferrer B, Asbrock N, Kathuria S, Piomelli D, Giuffrida A (2003) Effects of levodopa on endocannabinoid levels in rat basal ganglia: implications for the treatment of levodopa-induced dyskinesias. Eur J Neurosci 18:1607-1614.

Freund TF, Katona I, Piomelli D (2003) Role of endogenous cannabinoids in synaptic signaling. Physiol Rev 83:1017-1066.

Fusco FR, Martorana A, Giampa C, De March Z, Farini D, D'Angelo V, Sancesario G, Bernardi G (2004) Immunolocalization of $\mathrm{CB}_{1}$ receptor in rat striatal neurons: a confocal microscopy study. Synapse 53:159-167.

Gerdeman G, Lovinger DM (2001) $\mathrm{CB}_{1}$ cannabinoid receptor inhibits synaptic release of glutamate in rat dorsolateral striatum. J Neurophysiol 85:468-471.

Gerdeman GL, Ronesi J, Lovinger DM (2002) Postsynaptic endocannabinoid release is critical to long-term depression in the striatum. Nat Neurosci 5:446-451.

Glass M, Felder CC (1997) Concurrent stimulation of cannabinoid $\mathrm{CB}_{1}$ and dopamine $\mathrm{D}_{2}$ receptors augments cAMP accumulation in striatal neurons: evidence for a $G_{s}$ linkage to the $C_{1}$ receptor. J Neurosci 17:5327-5333.

Gubellini P, Picconi B, Bari M, Battista N, Calabresi P, Centonze D, Bernardi G, Finazzi-Agro A, Maccarrone M (2002) Experimental parkinsonism alters endocannabinoid degradation: implications for striatal glutamatergic transmission. J Neurosci 22:6900-6907.

Hájos N, Freund TF (2002a) Distinct cannabinoid sensitive receptors regulate hippocampal excitation and inhibition. Chem Phys Lipids 121:73-82.

Hájos N, Freund TF (2002b) Pharmacological separation of cannabinoid sensitive receptors on hippocampal excitatory and inhibitory fibers. Neuropharmacology 43:503-510.

Hájos N, Ledent C, Freund TF (2001) Novel cannabinoid-sensitive receptor mediates inhibition of glutamatergic synaptic transmission in the hippocampus. Neuroscience 106:1-4.

Herkenham M, Lynn AB, Little MD, Johnson MR, Melvin LS, de Costa BR, Rice KC (1990) Cannabinoid receptor localization in brain. Proc Natl Acad Sci USA 87:1932-1936.

Herkenham M, Lynn AB, Johnson MR, Melvin LS, de Costa BR, Rice KC (1991) Characterization and localization of cannabinoid receptors in rat brain: a quantitative in vitro autoradiographic study. J Neurosci 11:563-583.

Howlett AC, Mukhopadhyay S (2000) Cellular signal transduction by anandamide and 2-arachidonoylglycerol. Chem Phys Lipids 108:53-70.

Howlett AC, Bidaut-Russell M, Devane WA, Melvin LS, Johnson MR, Herkenham M (1990) The cannabinoid receptor: biochemical, anatomical and behavioral characterization. Trends Neurosci 13:420-423.

Huang CC, Lo SW, Hsu KS (2001) Presynaptic mechanisms underlying cannabinoid inhibition of excitatory synaptic transmission in rat striatal neurons. J Physiol (Lond) 532:731-748.

Hurley MJ, Mash DC, Jenner P (2003) Expression of cannabinoid $\mathrm{CB}_{1}$ receptor mRNA in basal ganglia of normal and parkinsonian human brain. J Neural Transm 110:1279-1288.

Jarrahian A, Watts VJ, Barker EL (2004) $D_{2}$ dopamine receptors modulate Galpha-subunit coupling of the $\mathrm{CB}_{1}$ cannabinoid receptor. J Pharmacol Exp Ther 308:880-886.

Jarvis SE, Zamponi GW (2001) Interactions between presynaptic $\mathrm{Ca}^{2+}$ channels, cytoplasmatic messengers and proteins of the synaptic vesicle release complex. Trends Pharmacol Sci 22:519-525.

Julian MD, Martin AB, Cuellar B, Rodríguez De Fonseca F, Navarro M, Moratalla R, Garcia-Segura LM (2003) Neuroanatomical relationship between type 1 cannabinoid receptors and dopaminergic systems in the rat basal ganglia. Neuroscience 119:309-318.

Katona I, Sperlágh B, Sík A, Köfalvi A, Vizi ES, Mackie K, Freund TF (1999) 
Presynaptically located $\mathrm{CB}_{1}$ cannabinoid receptors regulate $\mathrm{GABA}$ release from axon terminals of specific hippocampal interneurons. J Neurosci 19:4544-4558.

Katona I, Sperlágh B, Maglóczky Z, Sántha E, Köfalvi A, Czirják S, Mackie K, Vizi ES, Freund TF (2000) GABAergic interneurons are the targets of cannabinoid actions in the human hippocampus. Neuroscience 100:797-804.

Katona I, Rancz EA, Acsady L, Ledent C, Mackie K, Hajos N, Freund TF (2001) Distribution of $\mathrm{CB}_{1}$ cannabinoid receptors in the amygdala and their role in the control of GABAergic transmission. J Neurosci 21:9506-9518.

Kiss JP, Zsilla G, Vizi ES (2004) Inhibitory effect of nitric oxide on dopamine transporters: interneuronal communication without receptors. Neurochem Int 45:485-489.

Köfalvi A, Sperlágh B, Zelles T, Vizi ES (2000) Long-lasting facilitation of 4 -amino-n- $\left[2,3-{ }^{3} \mathrm{H}\right]$ butyric acid $\left(\left[{ }^{3} \mathrm{H}\right] \mathrm{GABA}\right)$ release from rat hippocampal slices by nicotinic receptor activation. J Pharm Exp Ther 295:453-462.

Köfalvi A, Vizi ES, Ledent C, Sperlágh B (2003) Cannabinoids inhibit the release of $\left[{ }^{3} \mathrm{H}\right]$ glutamate from rodent hippocampal synaptosomes via a novel $\mathrm{CB}_{1}$ receptor-independent action. Eur J Neurosci 18:1973-1978.

Lastres-Becker I, Cebeira M, de Ceballos ML, Zeng BY, Jenner P, Ramos JA, Fernández-RuizJJ (2001a) Increased cannabinoid $\mathrm{CB}_{1}$ receptor binding and activation of GTP-binding proteins in the basal ganglia of patients with Parkinson's syndrome and of MPTP-treated marmosets. Eur J Neurosci 14:1827-1832.

Lastres-Becker I, Fezza F, Cebeira M, Bisogno T, Ramos JA, Milone A, Fernández-Ruiz J, Di Marzo V (2001b) Changes in endocannabinoid transmission in the basal ganglia in a rat model of Huntington's disease. NeuroReport 12:2125-2129.

Lastres-Becker I, De Miguel R, Fernández-Ruiz JJ (2003) The endocannabinoid system and Huntington's disease. Curr Drug Targets CNS Neurol Disord 2:335-347.

Ledent C, Valverde O, Cossu G, Petitet F, Aubert JF, Beslot F, Bohme GA, Imperato A, Pedrazzini T, Roques BP, Vassart G, Fratta W, Parmentier M (1999) Unresponsiveness to cannabinoids and reduced addictive effects of opiates in $\mathrm{CB}_{1}$ receptor knockout mice. Science 283:401-404.

Liao C, Zheng J, David LS, Nicholson RA (2004) Inhibition of voltagesensitive sodium channels by the cannabinoid 1 receptor antagonist AM 251 in mammalian brain. Pharmacol Toxicol 94:73-78.

Maccarrone M, Gubellini P, Bari M, Picconi B, Battista N, Centonze D, Bernardi G, Finazzi-Agro A, Calabresi P (2003) Levodopa treatment reverses endocannabinoid system abnormalities in experimental parkinsonism. J Neurochem 85:1018-1025.

Mailleux P, Vanderhaeghen JJ (1992) Distribution of neuronal cannabinoid receptor in the adult rat brain: a comparative receptor binding radioautography and in situ hybridization histochemistry. Neuroscience 48:655-668.

Malone DT, Taylor DA (1999) Modulation by fluoxetine of striatal dopamine release following $\Delta^{9}$-tetrahydrocannabinol: a microdialysis study in conscious rats. Br J Pharmacol 128:21-26.

Matsuda LA, Bonner TI, Lolait SJ (1993) Localization of cannabinoid receptor mRNA in rat brain. J Comp Neurol 327:535-550.

Melis M, Gessa GL, Diana M (2000) Different mechanisms for dopaminergic excitation induced by opiates and cannabinoids in the rat midbrain. Prog Neuropsychopharmacol Biol Psychiatry 24:993-1006.

Milusheva EA, Dóda M, Baranyi M, Vizi ES (1996) Effect of hypoxia and glucose deprivation on ATP level, adenylate energy charge and $\left[\mathrm{Ca}^{2+}\right] \mathrm{O}-$ dependent and independent release of $\left[{ }^{3} \mathrm{H}\right]$ dopamine in rat striatal slices. Neurochem Int 28:501-507.

Monory K, Tzavara ET, Lexime J, Ledent C, Parmentier M, Borsodi A, Hanoune J (2002) Novel, not adenylyl cyclase-coupled cannabinoid binding site in cerebellum of mice. Biochem Biophys Res Commun 292:231-235.

Nakai T, Milusheva E, Baranyi M, Uchihashi Y, Satoh T, Vizi ES (1999)
Excessive release of $\left[{ }^{3} \mathrm{H}\right]$ noradrenaline and glutamate in response to simulation of ischemic conditions in rat spinal cord slice preparation: effect of NMDA and AMPA receptor antagonists. Eur J Pharmacol 366:143-150.

Nicholson RA, Liao C, Zheng J, David LS, Coyne L, Errington AC, Singh G, Lees G (2003) Sodium channel inhibition by anandamide and synthetic cannabimimetics in brain. Brain Res 978:194-204.

Nishizaki T (2004) ATP- and adenosine-mediated signaling in the central nervous system: adenosine stimulates glutamate release from astrocytes via $A_{2 \mathrm{a}}$ adenosine receptors. J Pharmacol Sci 94:100-102.

Pertwee RG (2004) Novel pharmacological targets for cannabinoids. Curr Neuropharmacol 2:9-29.

Phillips GR, Huang JK, Wang Y, Tanaka H, Shapiro L, Zhang W, Shan W, Arndt K, Frank M, Gordon RE, Gawinowicz MA, Zhao Y, Colman DR (2001) The presynaptic particle web: ultrastructure, composition, dissolution, and reconstitution. Neuron 32:63-77.

Pinheiro PS, Rodrigues RJ, Silva AP, Cunha RA, Oliveira CR, Malva JO (2003) Solubilization and immunological identification of presynaptic alpha-amino-3-hydroxy-5-methyl-4-isoxazolepropionic acid receptors in the rat hippocampus. Neurosci Lett 336:97-100.

Rebola N, Pinheiro PC, Oliveira CR, Malva JO, Cunha RA (2003) Subcellular localization of adenosine $A_{1}$ receptors in nerve terminals and synapses of the rat hippocampus. Brain Res 987:49-58.

Robbe D, Alonso G, Duchamp F, Bockaert J, Manzoni OJ (2001) Localization and mechanisms of action of cannabinoid receptors at the glutamatergic synapses of the mouse nucleus accumbens. J Neurosci 21:109-116.

Robbe D, Kopf M, Remaury A, Bockaert J, Manzoni OJ (2002) Endogenous cannabinoids mediate long-term synaptic depression in the nucleus accumbens. Proc Natl Acad Sci USA 99:8384-8388.

RodríguezJJ, Mackie K, Pickel VM (2001) Ultrastructural localization of the $\mathrm{CB}_{1}$ cannabinoid receptor in $\mu$-opioid receptor patches of the rat caudate putamen nucleus. J Neurosci 21:823-833.

Romero J, Berrendero F, Perez-Rosado A, Manzanares J, Rojo A, FernándezRuiz JJ, de Yebenes JG, Ramos JA (2000) Unilateral 6-hydroxydopamine lesions of nigrostriatal dopaminergic neurons increased $\mathrm{CB}_{1}$ receptor mRNA levels in the caudate-putamen. Life Sci 66:485-494.

Romero J, Lastres-Becker I, de Miguel R, Berrendero F, Ramos JA, FernándezRuiz J (2002) The endogenous cannabinoid system and the basal ganglia: biochemical, pharmacological, and therapeutic aspects. Pharmacol Ther 95:137-152.

Ronesi J, Gerdeman GL, Lovinger DM (2004) Disruption of endocannabinoid release and striatal long-term depression by postsynaptic blockade of endocannabinoid membrane transport. J Neurosci 24:1673-1679.

Shen M, Thayer SA (1998) The cannabinoid agonist Win55,212-2 inhibits calcium channels by receptor-mediated and direct pathways in cultured rat hippocampal neurons. Brain Res 783:77-84.

Sieradzan KA, Fox SH, Hill M, Dick JP, Crossman AR, Brotchie JM (2001) Cannabinoids reduce levodopa-induced dyskinesia in Parkinson's disease: a pilot study. Neurology 57:2108-2111.

Szabo B, Dörner L, Pfreundtner C, Nörenberg W, Starke K (1998) Inhibition of GABAergic inhibitory postsynaptic currents by cannabinoids in rat corpus striatum. Neuroscience 85:395-403.

Szabo B, Müller T, Koch H (1999) Effects of cannabinoids on dopamine release in the corpus striatum and the nucleus accumbens in vitro. J Neurochem 73:1084-1089.

Terrian DM, Dorman RV, Damron DS, Gannon RL (1991) Displacement of endogenous glutamate with D-aspartate: an effective strategy for reducing the calcium-independent component of glutamate release from synaptosomes. Neurochem Res 16:35-41.

van der Stelt M, Di Marzo V (2003) The endocannabinoid system in the basal ganglia and in the mesolimbic reward system: implications for neurological and psychiatric disorders. Eur J Pharmacol 480:133-150.

White R, Hiley CR (1998) The actions of the cannabinoid receptor antagonist, SR141716A, in the rat isolated mesenteric artery. Br J Pharmacol 125:689-696. 